\title{
MEK1 is required for the development of NRAS-driven leukemia
}

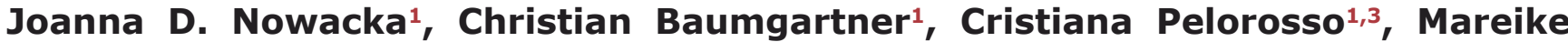 \\ Roth $^{2}$, Johannes Zuber ${ }^{2}$ and Manuela Baccarini ${ }^{1}$ \\ ${ }^{1}$ Department of Microbiology and Immunobiology, Max F. Perutz Laboratories, University of Vienna, Vienna, Austria \\ 2 Research Institute of Molecular Pathology, Vienna, Austria \\ ${ }^{3}$ Pediatric Neurology, Neurogenetics and Neurobiology Unit and Laboratories, A. Meyer Children's Hospital-University of \\ Florence, Florence, Italy \\ Correspondence to: Manuela Baccarini, email: manuela.baccarini@univie.ac.at
}

Keywords: MEK 1, leukemia, NRAS, MYC

Received: July 20, $2016 \quad$ Accepted: September 29, $2016 \quad$ Published: October 10, 2016

\section{ABSTRACT}

The dual-specificity kinases MEK1 and MEK2 act downstream of RAS/RAF to induce ERK activation, which is generally considered protumorigenic. Activating MEK mutations have not been discovered in leukemia, in which pathway activation is caused by mutations in upstream components such as RAS or FIt3. The anti-leukemic potential of MEK inhibitors is being tested in clinical trials; however, downregulation

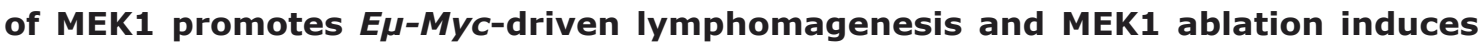
myeloproliferative disease in mice, raising the concern that MEK inhibitors may be inefficient or counterproductive in this context. We investigated the role of MEK1 in the proliferation of human leukemic cell lines and in retroviral models of leukemia. Our data show that MEK1 suppression via RNA interference and genomic engineering does not affect the proliferation of human leukemic cell lines in culture; similarly, MEK1 ablation does not impact the development of MYC-driven leukemia in vivo. In contrast, MEK1 ablation significantly reduces tumorigenesis driven by Nras alone or in combination with Myc. Thus, while MEK1 restricts proliferation and tumorigenesis in some cellular and genetic contexts, it cannot be considered a tumor suppressor in the context of leukemogenesis. On the contrary, its role in NRAS-driven leukemogenesis advocates the use of MEK inhibitors, particularly in combination with PI3K/AKT inhibitors, in hematopoietic malignancies involving RAS activation.

\section{INTRODUCTION}

Leukemias are genetically and biologically heterogeneous hematopoietic malignancies characterized by the expansion of transformed cells which interferes with the proper differentiation and maturation of all blood lineages. Leukemia can be categorized based on the lineage origin of malignant cells and their maturation status, forming four major groups that account for $70 \%$ of all human leukemia: acute myeloid leukemia (AML), acute lymphoblastic leukemia (ALL), chronic myeloid leukemia (CML), and chronic lymphocytic leukemia (CLL) [1]. Neoplastic transformation is initiated by activating mutations of proto-oncogenes or loss-of function mutations in tumor suppressor genes occurring in the hematopoietic stem cells (HSCs) or multipotent progenitor cells (MPPs) [2].
The RAF/MEK/ERK pathway is a central regulator of fundamental cellular processes including cell proliferation, survival, differentiation, apoptosis, motility and metabolism. It is activated by the small GTPase RAS downstream of growth factor and cytokine receptors and plays a key role in the development. Deregulation of the pathway has been shown to lead to various developmental disorders, as well as carcinogenesis $[3,4]$. In particular, the RAS/RAF/MEK/ERK pathway contributes to a number of myeloproliferative disorders $[5,6]$, to myelodysplastic syndrome (MDS) [7], and to hematopoietic malignancies [8]. Mutational activation of the ERK cascade may occur at multiple levels - at the receptor (for example FLT3, KIT, PDGFP), at GTPases (RAS) or at the kinase cascade itself (RAF); additionally, the ERK pathway can be activated by fusion proteins resulting from chromosomal translocations such as BCR-ABL. Consistent with this, 
ERK is activated in $83 \%$ of AML [9] and 35\% of ALL [10]. However, while activating mutations in the upstream components of the pathway are quite frequent in cancer, mutations of MEK $1 / 2$ are very sporadic. To date, only a few mutations that increase the activity of MEK1 have been described in ovarian cancer, lung cancer, melanoma and colon cancer (recently reviewed in [11]). Several studies have shown that overexpression of active MEK1 is transforming [8], but gain-of-function mutations in MEK or ERK have not been detected in leukemia samples. MEK inhibitors and other pathway inhibitors are in clinical trials and have moderate efficacy as single agents in AML and ALL, particularly in leukemias harboring RAS pathway mutations; synergy has been shown with compounds inhibiting other signaling pathways including the PI3K/ AKT pathway $[12,13]$.

MEK1 and MEK2 are dual-specificity kinases that share a common mechanism of activation by RAF and a common target, ERK1/2. Due to their high structural similarity, common mechanisms of activation, and common substrates, MEK1 and MEK2 have traditionally been considered functionally redundant. Conditional ablation experiments, however, have revealed that MEK1 plays an essential role in the regulation of strength and duration of MEK2/ERK [14] and AKT signals [15]. Mice carrying an epiblast-restricted deletion of the Mek1 gene are born at Mendelian ratios without any gross abnormalities, although higher ERK1/2 activation levels can be observed in the embryos as well as in the epidermis and brain of young mice [14]. However, MEK1 KO mice show decreased survival rate and develop myeloproliferative and lupus-like autoimmune disorders associated with AKT activation in hematopoietic cells and tissues [15]. In addition, data from an in vivo RNA interference screen for tumor suppressor genes in a mouse E $\mu$-MYC-driven lymphoma model have revealed that downregulation of MEK1 accelerates the development of this disease [16]. Although the exact mechanism has not been delineated, together these results suggest that MEK1 may suppress proliferation and even tumorigenesis in the context of the hematopoietic system, raising concerns about the safety of treatments inhibiting MEK in leukemia. Against this backdrop, we set out to investigate the impact of MEK1 ablation on the initiation and promotion of leukemogenesis.

\section{RESULTS \& DISCUSSION}

\section{MEK1 down-regulation confers no selective advantage to human leukemia cell lines}

We employed RNAi technology to knockdown (KD) MEK1 in human leukemia cell lines and investigate its role in their proliferation. We used a previously described short-hairpin RNA (shRNA) TetON system (Figure 1A), in which leukemic cells are first transduced with lentiviral pseudoparticles carrying the reverse tetracycline-controlled transactivator (rtTA3) and an ecotropic receptor [17]. The established cell lines (denoted as R) were further infected with retroviral vectors encoding Tet-inducible MEK1 shRNAs embedded in the optimized microRNA stem (miR-E) located in the 3'UTR of GFP gene [18].

We first tested the effect of MEK1 suppression in K562 cell lines. The human erythromyeloblastoid leukemia cell line K562 expresses the BCR-ABL fusion protein, known to initiate the ERK pathway by direct activation of RAS proteins [19, 20]. Flow cytometry (FACS) analysis of the established batch-cultures revealed that more than $90 \%$ of cells expressed the GFP-miR-E cassette upon doxycycline treatment (Figure 1B). Tetinduced GFP expression and efficient downregulation of MEK1 by all shRNAs were verified by immunoblotting (Figure 1C). ERK expression and phosphorylation were not affected by MEK1 knock-down (Figure 1C).

We next investigated the impact of MEK1 downregulation on K562 cells proliferation in a competition assay. K562 MEK1 KD cell lines were pre-treated with doxycycline, mixed with the parental K562R cells and co-cultured in medium supplemented with $10 \%$ or $0.5 \%$ FCS (Figure 1D, 1E). Although the percentage of GFPmiR-E expressing cells in all four MEK1 KD cell lines tested showed some variation, MEK1 suppression had no major effect on proliferation and survival compared to the control Ren shRNA cell line. The only exception was one of the four MEK1 shRNA (MEK1.1916) clones, which proliferated faster than all others in the low serum $(0.5 \%)$. This effect was not observed in the remaining 3 cell lines, and therefore likely resulted from shRNA specific offtarget effects or clonal variation.

We applied the same strategy to knock-down MEK1 in the THP-1 human monocytic leukemia cell line, harboring the $\mathrm{NRAS}^{\mathrm{G} 12 \mathrm{D}}$ mutation and a $M L L-A F 9$ fusion $[21,22]$. In these cells, NRAS ${ }^{\mathrm{G} 12 \mathrm{D}}$ is predicted to constitutively activate MEK/ERK [23]. In addition, MLLAF9 has been shown to directly bind to the promoter of erythropoietin-producing hepatoma-amplified sequence (epha7) receptor tyrosine kinases, leading to its upregulation and subsequent MEK-dependent ERK phosphorylation [24].

The results were similar to those obtained using the K562 cell line. We observed Tet-regulated expression of GFP in batch cultures (more than $75 \%$ of the cells positive for the expression of GFP-miR-E cassette in shRNA 1361, 1918 and 2100 lines; 61\% in the 1916 lines; Figure 2A) and efficient down-regulation of MEK1 protein levels (Figure 2B). Clonal variation could be observed in both ERK expression (upregulated in shRNA 1361 and 1916 lines) and phosphorylation (slight upregulation in shRNA 1918 and 2100 lines (Figure 2B). However, MEK1 down- 

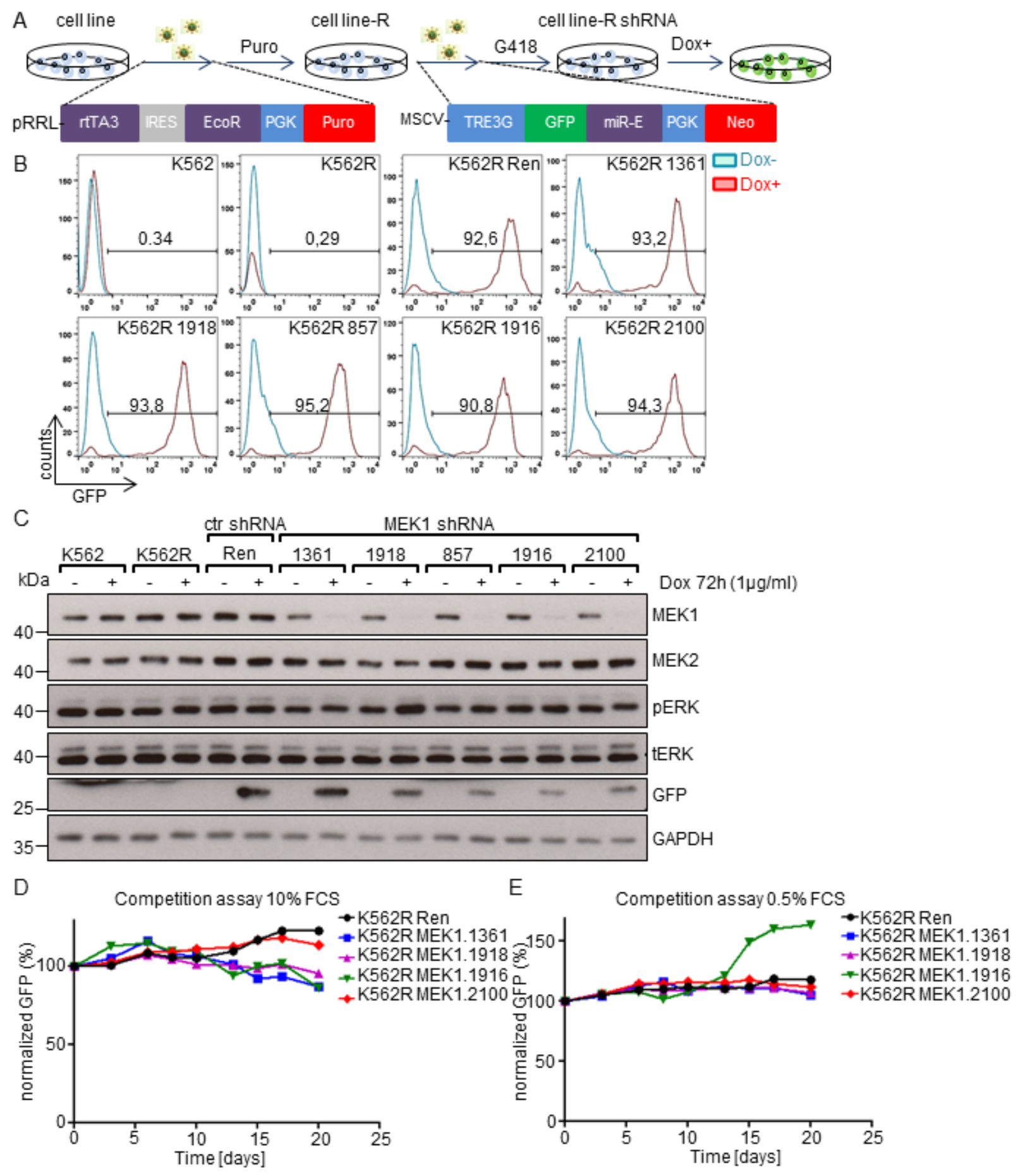

Figure 1: MEK1 knock-down does not confer a selective advantage to human K562 leukemia cell line. A. Generation of MEK1 knock-down cell lines. K562 cells were transduced with lentiviral particles expressing a Tet responsive transactivator (rtTA3) and ecotropic receptor. After puromycin selection the transduced cells (K562R) were infected with retroviral particles carrying a GFP reporter and shRNAs against the MEK1 gene embedded in a microRNA stem (miR-E)(shRNA\#1361,\#1916, \#857,\#1918, \#2100). The GFP-miR-E cassette is under the control of an inducible tetracyclin responsive promoter and its expression is activated by doxycyline (Dox) treatment. B. FACS analysis of batch cultures showing strong expression of the GFP-mir-E cassette. The numbers indicate the percentage of GFP ${ }^{+}$ cells. C. Efficient knock-down of MEK1 induced by Dox treatment in established cell lines. GAPDH is shown as a loading control. tERK, total ERK; pERK, phosphorylated ERK. The Western blot is representative of 3 independent experiments. D. and E. Effect of MEK1 KD on cell proliferation in competition assays. Dox pre-treated K562R Ren ctr or MEK1 KD cells expressing shRNAs and GFP reporter were mixed in 1:1 ratio with K562R cells (no GFP). Cells were cultured in the presence of $10 \%$ (D) or $0.5 \%$ FCS (E) and passaged every $2-3$ days, depending on confluency. After each passage, an aliquot of the co-culture was evaluated for the $\%$ of GFP ${ }^{+}$cells and normalized to the initial $\mathrm{GFP}^{+}$cells content on day 0 . 
A
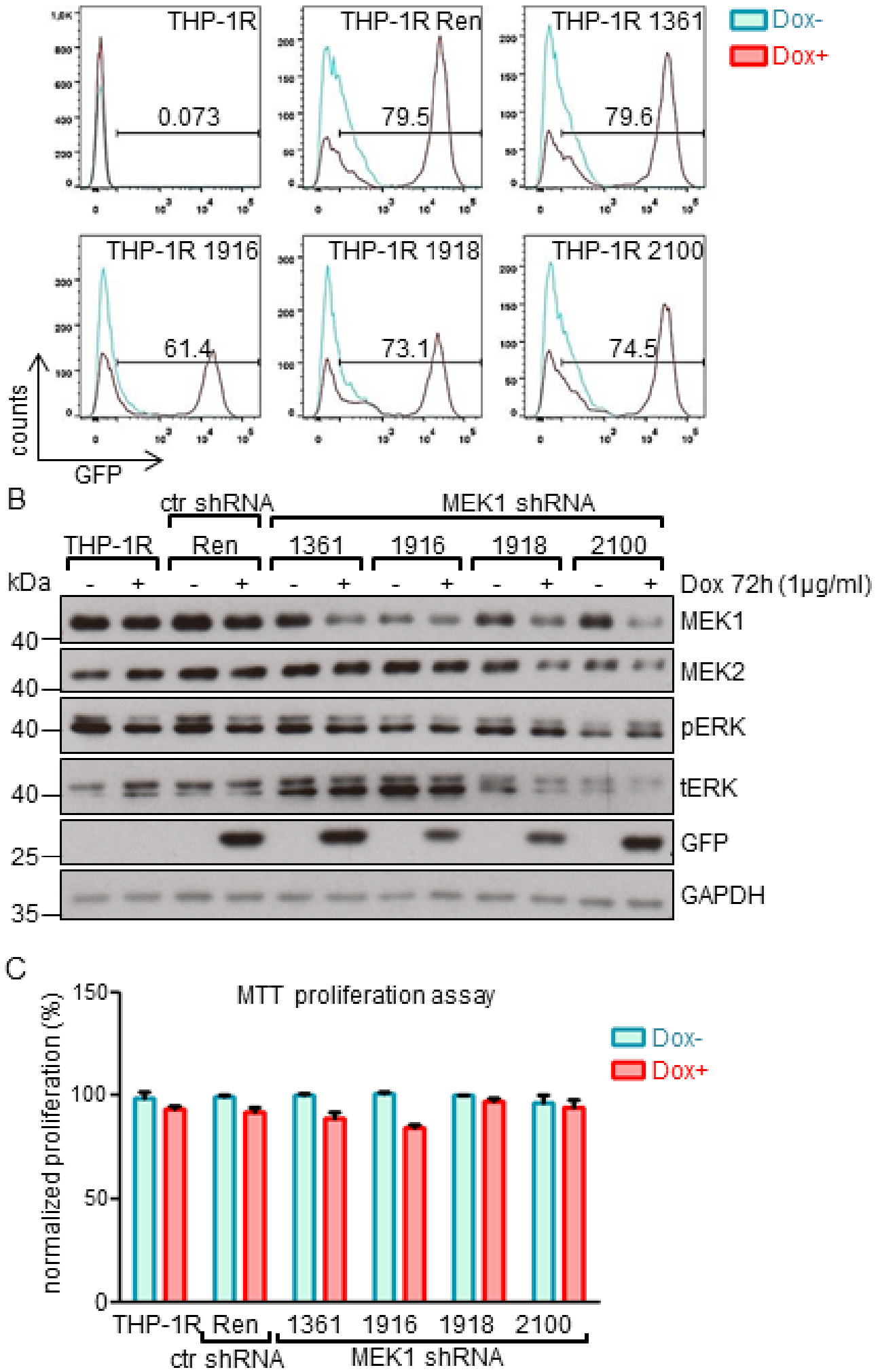

Figure 2: MEK1 knock-down has no impact on the proliferation of human THP-1 leukemia cell line expressing NRAS ${ }^{\text {G12D }}$ and MLL-AF9 oncogenes. A. MEK1 KD cells were generated as described in the legend to Figure 1. FACS analysis of batch cultures showing strong expression of the GFP-mir-E cassette. The numbers indicate the percentage of GFP ${ }^{+}$cells. B. MEK1 knockdown efficiency in established cell lines after 72h of Dox-induced expression of shRNA. GAPDH is shown as a loading control. tERK, total ERK; pERK, phosphorylated ERK. The Western blot is representative of 3 independent experiments. C. MTT proliferation assay shows no significant difference between the proliferation of WT and KD cells after 7 days in culture. 

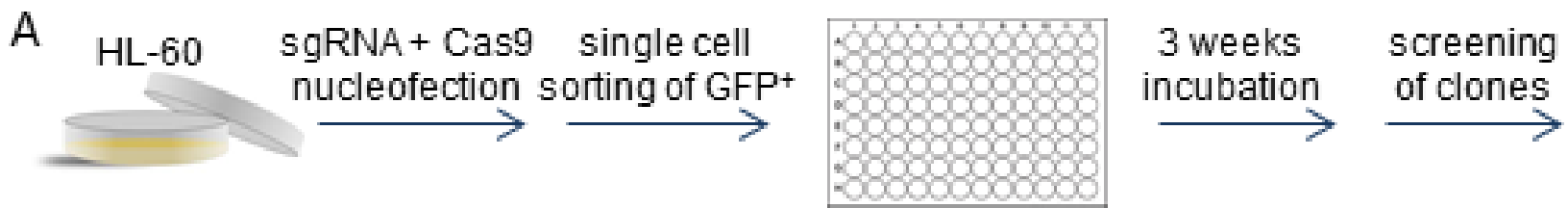

B

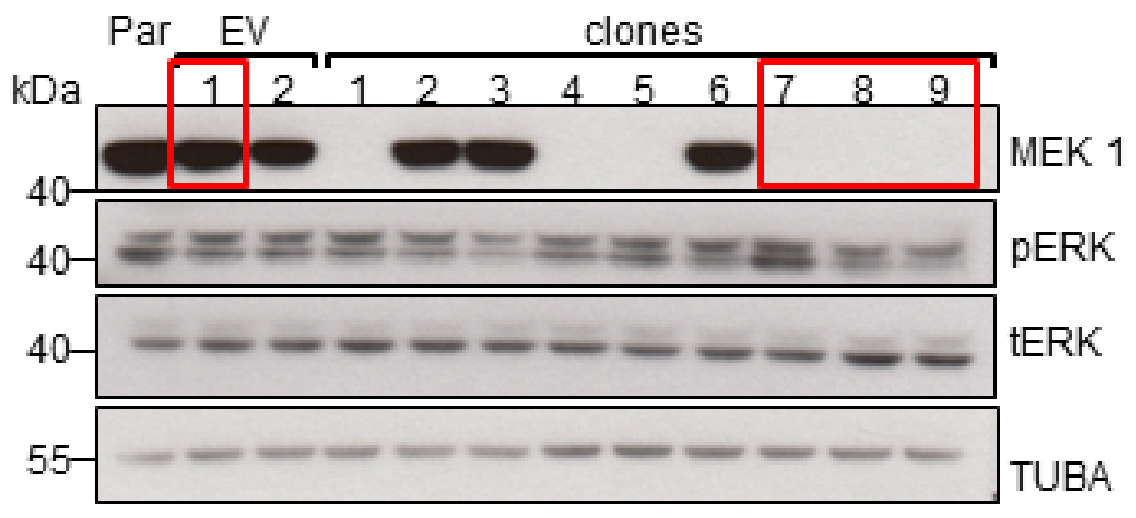

C
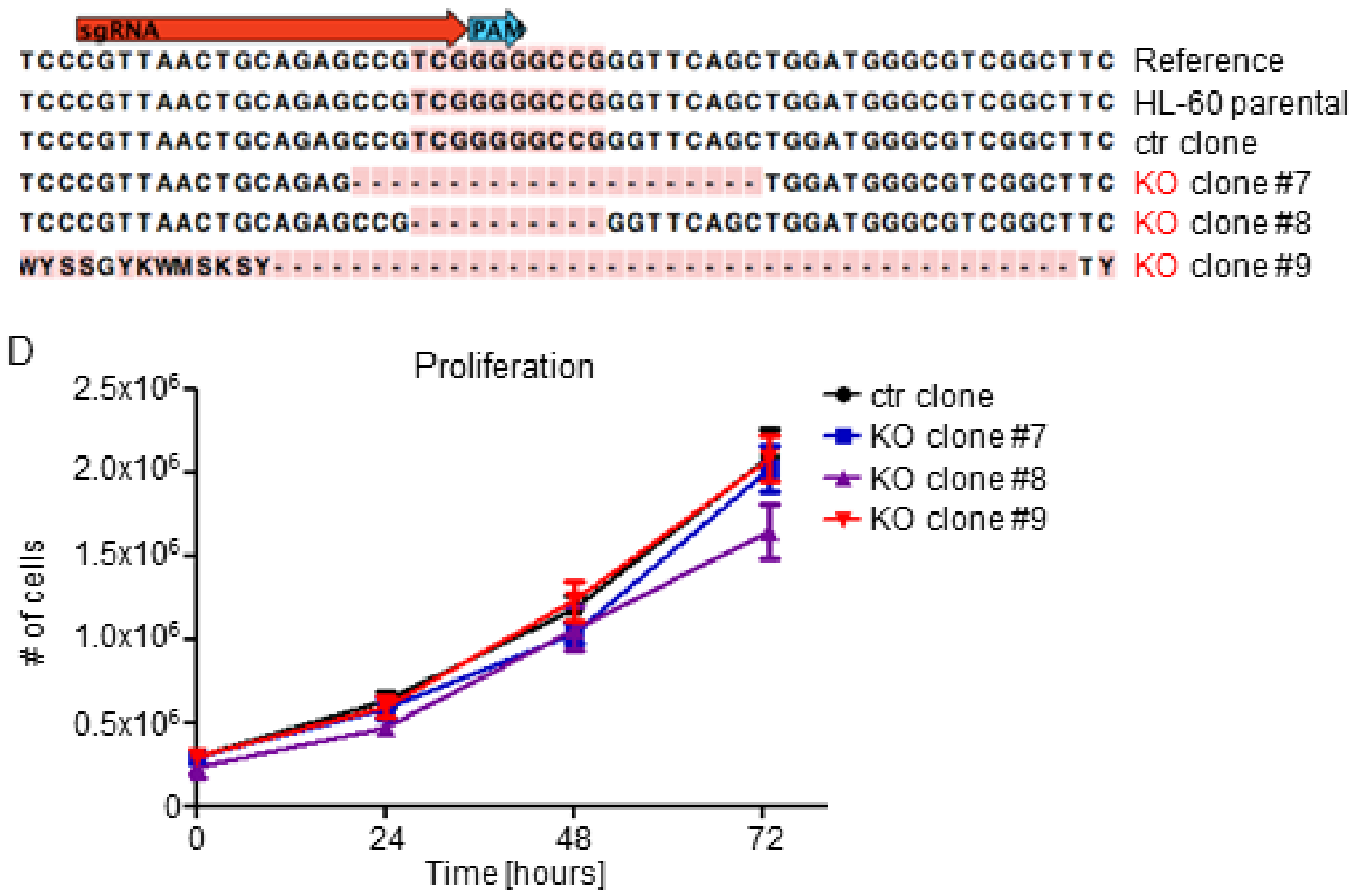

Figure 3: MEK1 knock-out has no impact on the proliferation of the human HL-60 leukemia cell line carrying MYC amplification and expressing NRAS ${ }^{\text {Q61L }}$ oncogenes. A. Schematic of CRISPR-Cas9 mediated MEK1 KO: HL-60 human leukemia cells were transiently nucleofected with a vector carrying Cas9-GFP and a single guide RNA targeting exon 1 of $\boldsymbol{M E K 1}$ gene. After 3 weeks of incubation, single cell clones were screened for successful MEK1 ablation. B. Two thirds of the clones screened showed successful MEK1 KO. The Western blot is a representative of 3 independent experiments. Tubulin A is shown as a loading control. tERK, total ERK; pERK, phosphorylated ERK. Par, HL-60 parental cell line; EV, HL-60 cells transfected with Cas9 vector without RNA guides. The red boxes show the clones chosen for further experiments. C. Sequencing of selected clones revealed efficient target site cleavage. D. Proliferation assay shows no significant difference between proliferation of control (ctr) and KO clones. 
regulation did not affect the proliferation of THP-1 cells (Figure 2C).

RNAi technology enables the generation of hypomorphic expression states, which are distinct from a complete KO. We therefore applied CRISPRCas9 technology [25] to knock-out MEK1 in HL-60 promyelocytic leukemia cells, which in addition to the NRAS ${ }^{\mathrm{Q} 61 \mathrm{~L}}$ mutation harbors an amplification of MYC (CMYC) [26], whose enforced expression was shown to cooperate with MEK1 silencing in B cell leukemogenesis [16].

HL-60 cells nucleofected with a single guide RNA (sgRNA) against $M E K 1$ exon1 and a Cas9-GFP fusion protein were FACS-sorted and grown as single cell clones (Figure 3A). Immunoblot analysis showed successful MEK1 knock-out in 2 out of 3 screened clones (Figure 3B). Indel formation in the sgRNA target site was confirmed by sequencing (Figure 3C). ERK expression

A

A

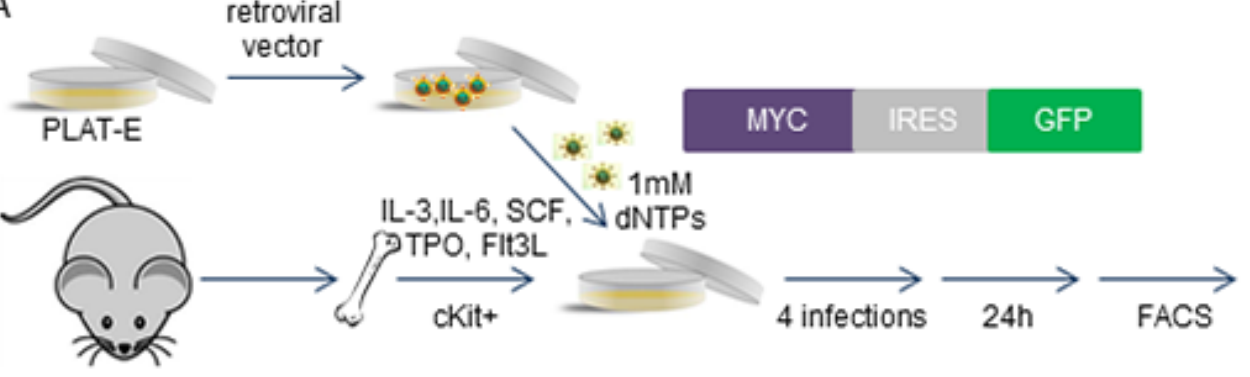

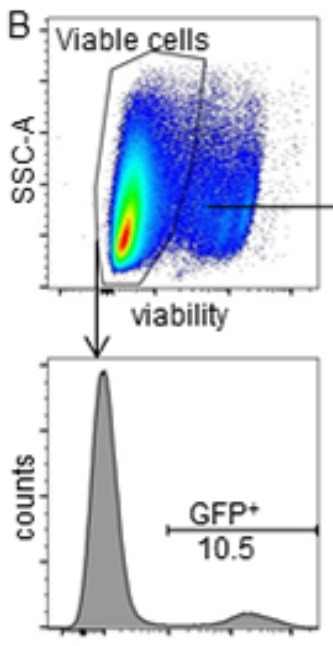

GFP

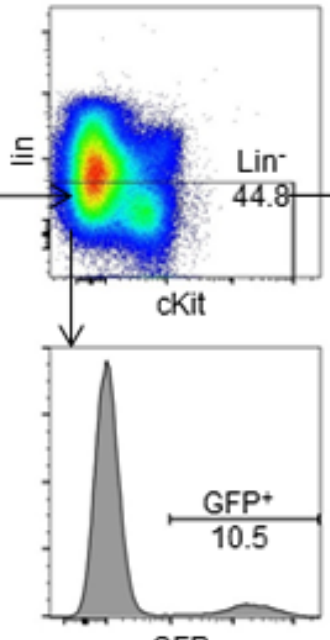

GFP

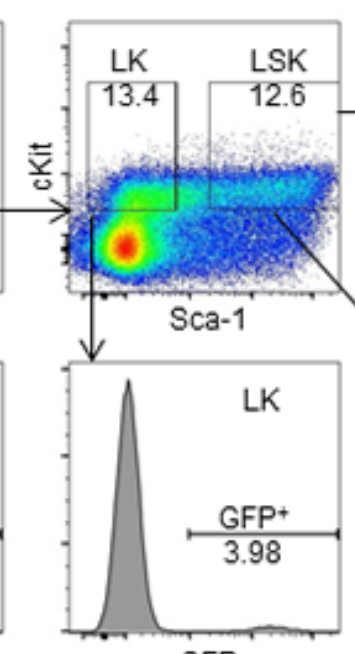

GFP

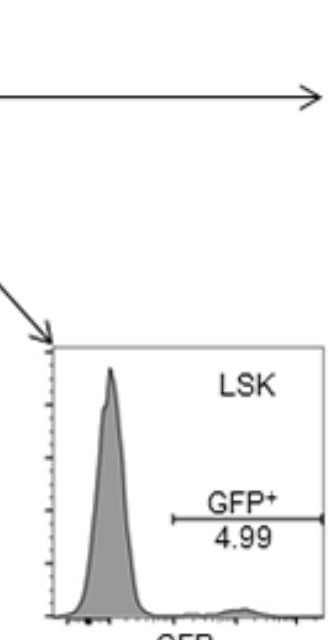

GFP

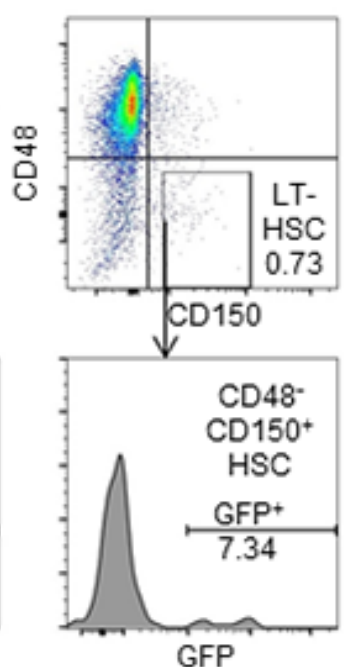

GFP

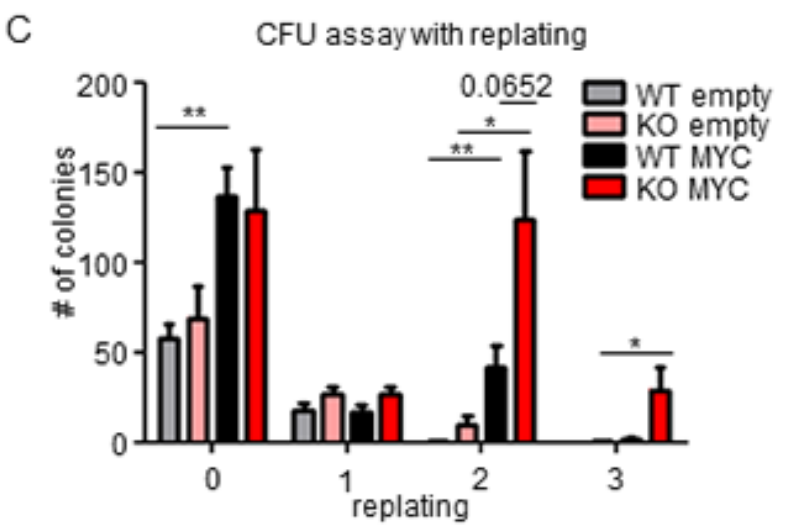

Figure 4: Cooperation of MEK1 ablation with MYC overexpression in semisolid culture. A. Schematic of the retroviral transduction protocol. Retroviruses carrying an expression cassette containing $M y c$ and a GFP reporter were produced in Platinum-E packaging cells and used for infection of c-Kit-enriched BM cells. B. Successful transduction of hematopoietic stem cells. Top panel: gating strategy; from left to right, viable cells, Lin- cells, committed progenitors (LK), multipotent progenitors and stem cells (LSK). The bottom panels show the $\%$ of $\mathrm{GFP}^{+}$cells in the boxed areas of the top panel. C. Colony forming unit (CFU) assay with MYC transduced Mek1 ${ }^{f /+}$ (WT) or Meklff; $\operatorname{Sox} 2 \mathrm{Cre}(\mathrm{KO})$ cells indicating cooperation of MEK1 ablation and MYC in a replating assay measuring self-renewing potential. 
was slightly increased in clones 8 and 9, while clone 7 showed increased ERK phosphorylation. However, we did not observe any differences in the proliferation rate of the control cells (wild type (WT) cells transfected with Cas9 only) and knock-out (KO) clones (Figure 3D).

Together, the data in Figures 1-3 indicate that MEK1 knock-down or knockout does not correlate with increased ERK phosphorylation in three human leukemia cells lines; a potential explanation of this fact is that output and feedback might both be reduced in MEK1-deficient cells, resulting in (nearly) equal levels of pERK. In addition, neither knock-down nor knock-out of MEK1 influenced the proliferation of human leukemia cell lines harboring oncogenic changes leading to the activation of the ERK pathway. All these cell lines, however, also contain loss of function mutations of the TP53 tumor suppressor gene [27]. It is possible that in the context of so many genomic alterations, the impact of MEK1 down-regulation is marginal. Alternatively, MEK1 might not influence the progression of the established disease, but rather play a role in its initiation.

\section{MEK1 ablation cooperates with MYC oncogene in semisolid culture}

To investigate the role of MEK1 in the initiation of leukemia, we first examined the cooperation of MEK1 ablation with MYC in culture. To this end, we developed an optimized protocol for the transduction of $\mathrm{cKit}^{+}$bone marrow hematopoietic stem and progenitor cells (BM HSPCs), which were shown to be the cells of origin in various leukemia models [28-30]. BM HSPCs were cultured in a cytokine cocktail containing IL-3, IL-6, SCF, TPO and Flt-3 ligand [31]. After 18 hrs in culture, cells were infected with retroviral pseudoparticles encoding an expression cassette harboring the mouse $M y c$ gene and a GFP reporter in medium supplemented with $1 \mathrm{mM}$ dNTPs to improve retroviral reverse transcription, inefficient in quiescent BM cells due to their low dNTP levels [32] (Figure 4A). FACS analysis showed successful transduction of both committed progenitor cells (LK; $\left.\mathrm{lin}^{-}, \mathrm{cKit}^{+}, \mathrm{Sca}^{-}\right)$and multipotent progenitor and stem cells (LSK; lin, cKit $^{+}, \mathrm{Sca}^{+}{ }^{+}$; Figure 4B). Further discrimination of the LSK population using CD48 and CD150 markers revealed enhanced transduction of the LSK, CD48-, CD150+ subpopulations, enriched for hematopoietic stem cells.

Next, we used methylcellulose colony assays to assess the impact of MEK1 ablation on the repopulation capacity of $M y c$-transduced BM HSPCs. Overexpression of MYC increased the number of colony forming cells (CFCs) approx. 2.5 fold in both MEK1 WT and KO cells (Figure 4C). After the first replating, the number of CFCs decreased drastically in all tested conditions. However, Myc transduced MEK1 KO cells performed significantly better than their WT counterpart in the second replating, and were the only population able to proliferate in the next round. These data are in line with the previously published observation that MYC represses the selfrenewing capacity of HSCs and does not stimulate the colony-forming activity of myeloid progenitors [33, 34]. However, the increased numbers of CFCs produced by MEK1 KO MYC cells in the second and third replating suggested that MEK1 ablation cooperates with MYC and enhances the repopulating potential of $M y c$ transduced cells.

\section{MEK1 ablation does not impact the survival or the disease spectrum in a MYC-driven leukemia model}

We next tested the impact of MEK1 ablation on the initiation and progression of MYC-driven leukemia. Lethally irradiated mice were transplanted with MEK1 WT or KO BM cells transduced with Myc $(3 \%$ in protective WT BM; Figure 5A, 5B). All mice injected with $\mathrm{WT}_{\mathrm{MYC}}^{+}$cells succumbed to the disease within 3 months (Figure 5C) and developed mild to medium hepatomegaly and splenomegaly (Figure 5D). The expansion of $\mathrm{MYC}^{+}$cells was evident in blood (ranging from $10-60 \%$ ), BM (up to $70 \%$ ), spleen (up to $40 \%$ ) and lymph nodes (5-60\%) (Figure 5F). FACS analysis revealed that leukemic cells expressed a range of lineage markers that varied significantly between individual mice but belonged mostly to myeloid and B cell lineage (Figure $1 \mathrm{G}$ and Supplementary Figure 1). The ablation of MEK1 did not accelerate leukemogenesis (median survival for both groups $=74$ days; Figure $5 \mathrm{C}$ ), nor did it lead to major changes in the disease spectrum (Figure 5G and Supplementary Figure 1). Compared to the WT $\mathrm{MYC}^{+}$cohort, the animals transplanted with $\mathrm{KO} \mathrm{MYC}^{+}$ cells showed a tendency towards increased white blood cells counts and more profound anemia (Figure 5E); one out of five mice transplanted with $\mathrm{KO} \mathrm{MYC}^{+}$cells presented with an enlarged thymus with accumulation of transformed, undifferentiated T cells (Figure 5D and data not shown). In conclusion, mice transplanted with either MEK1 WT or KO MYC overexpressing cells developed a broad spectrum of diseases (MPD-like, mixed myeloid and B cells, T-ALL).

Multiple studies have demonstrated the leukemogenic potential of enforced overexpression of MYC using retroviral vectors; however, the results of these studies vary dramatically depending on the cell type used in the infection. MYC overexpression in 5'FU treated $\mathrm{BM}$ cells was sufficient to promote the development of rapid AML [35], while in another study using lineagedepleted BM cells it failed to do so [33]. On the other hand, fetal liver cells transduced with $M y c$ retroviruses produced low-frequency, long-latency lymphomas [36]. In our setting, overexpression of MYC led to a mixed 
disease spectrum, probably resulting from leukemogenic transformation of cells in various differentiation stages; MEK1 ablation, however, did not have any significant impact on either survival or disease spectrum.

This finding was unexpected in view of the enhanced repopulating capacity of $M y c$ transduced, MEK1 KO BM cells in the CFU assay, as well as in view of the effect of MEK1 downregulation in the E $\mu$-MYC pre-B lymphoma model [16]. The first discrepancy could be the result of the different experimental conditions (in vitro culture vs. exposure to the BM niche). The obvious explanations for the discrepancy between our experiment and the results obtained in the E $\mu$-MYC pre-B lymphoma model are the difference in the onset and type of the disease; in the lymphoma model, MYC was expressed exclusively in pre-B progenitor cells, while we targeted all lineages

A
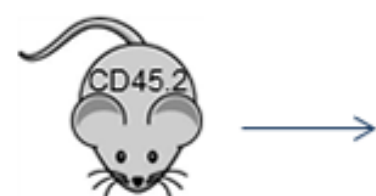

Ly5.2 MEK1 +/+':Vav-iCre + (WT)

Ly5.2 MEK1 F/F;Vav-iCre + (KO)

B

\begin{tabular}{|c|c|c|}
\hline & WT & KO \\
\hline $\begin{array}{c}\text { mCherry } \\
\text { cells }\end{array}$ & $2.26 \%$ & $3.18 \%$ \\
\hline
\end{tabular}

C

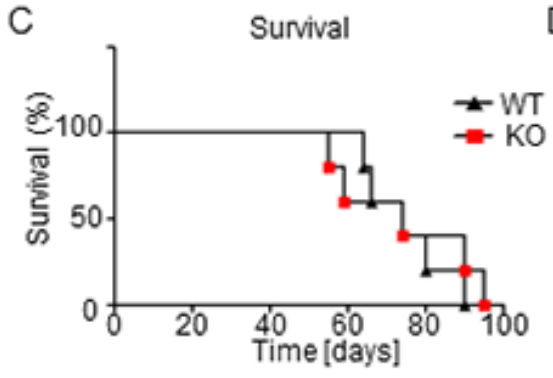

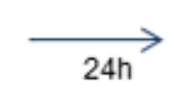

BM c-kit+ cells

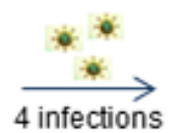

MYC

GFP

\section{$\overrightarrow{\text { sortmCherry }}$} positive cells

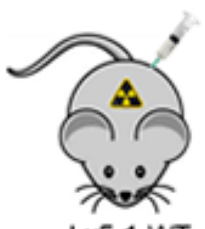

Ly5.1 WT $1 \times 10^{6}$ protective WT cells + $3 \times 10^{4}$ mCherry positives ( $3 \%$ )

$F$
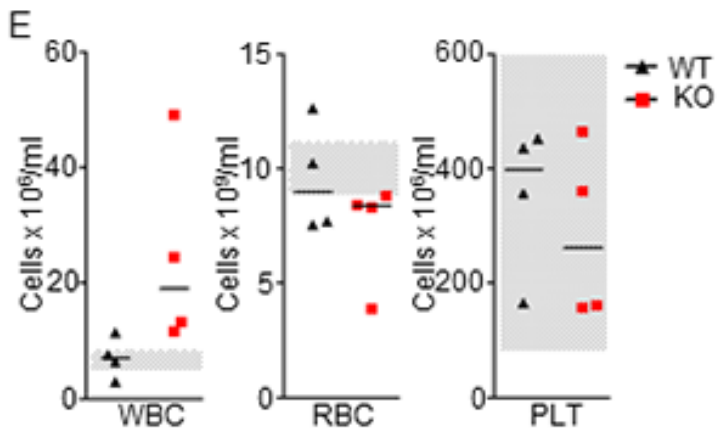

$\mathrm{F}$
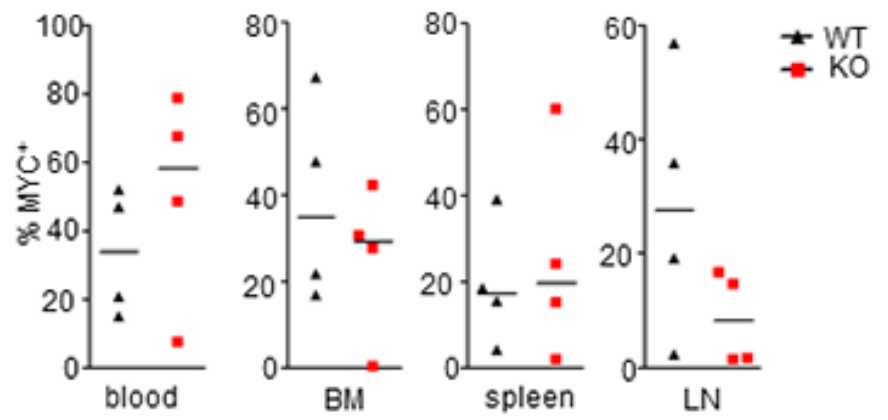

G

\begin{tabular}{|l|l|l|}
\hline Disease & WT & KO \\
\hline MPD-like & $3 / 5$ & $2 / 5$ \\
\hline Mixed myeloid and B-cell & $1 / 5$ & $1 / 5$ \\
\hline T-ALL & $0 / 5$ & $1 / 5^{\star}$ \\
\hline Other & $1 / 5$ & $1 / 5$ \\
\hline
\end{tabular}

Figure 5: MEK1 ablation does not significantly impact survival or disease spectrum in a MYC-driven leukemia model. A. Schematic of experimental procedure. c-Kit ${ }^{+}$-enriched BM cells were transduced with retroviral particles coding for $M y c$ and mCherry. $24 \mathrm{~h}$ after the last infection, $\mathrm{MYC}^{+}$cells were sorted, mixed with protective BM and injected in lethally irradiated WT mice $\left(3 \times 10^{4} \mathrm{WT}\right.$ or $\mathrm{KO} \mathrm{MYC}^{+}$cells in $1 \times 10^{6}$ protective WT BM per mouse). B. Initial transduction efficiency. C. Kaplan-Meier plot depicting the survival of recipients transplanted with WT or MEK1 KO MYC cells. D. Moderate hepatomegaly and splenomegaly in mice transplanted with both WT and $\mathrm{KO}_{\mathrm{MYC}}^{+}$cells. Grey boxes indicate the physiological weight range. E. Mice transplanted with $\mathrm{KO}^{\mathrm{MYC}} \mathrm{C}^{+}$cells show a tendency towards increased white blood cells (WBC) counts and more profound anemia (RBC) compared to the mice transplanted with WT $\mathrm{MYC}^{+}$cells. Platelets (PLT) counts are similar and in the normal range. Grey boxes indicate the physiological range. F. Moribund animals transplanted with either WT or KO MYC ${ }^{+}$cells show expansion of $\mathrm{MYC}^{+}$cells in blood, BM, spleen, and lymph nodes (LN). G. A broad spectrum of diseases develop in mice transplanted with both $\mathrm{WT}$ and $\mathrm{KO}_{\mathrm{MYC}}^{+}$cells. The asterisk in $\mathbf{D}$ and $\mathbf{J}$ indicates one mouse with T-ALL. 
causing the development of myeloid and mixed myeloid/B cell malignancies. Additionally, in the system we used the onset of the disease is rapid (2-3 months); in the pre-B lymphoma model, the mice remained disease-free for the period of more than 180 days and MEK1 down-regulation accelerated the onset of the disease to 2-3 months [16]. Finally, in our experiments MEK1 was completely ablated, as opposed to incomplete downregulation by RNAi.

Together, our and previous studies [16] demonstrate that while MEK1 downregulation has protumorigenic effects in certain contexts, MEK1 does not act as a generally relevant tumor suppressor gene in MYC-driven hematopoietic cancers of different origin.

\section{MEK1 ablation prolongs the survival of mice in leukemia models driven by NRAS ${ }^{\mathrm{G} 12 \mathrm{D}}$ and NRAS ${ }^{\text {G12D/MYC }}$}

We next investigated whether MEK1 ablation would have an impact on the development of leukemia driven by its upstream activator NRAS. Activating NRAS mutations have been observed in $8-11 \%$ of AML [37], 20\% of juvenile myelomonocytic leukemia (JMML) [38] and 8\% of T lymphomas and T leukemias [39], making NRAS the most frequently mutated RAS isoform in both lymphoid and myeloid malignancies.

Lethally irradiated mice were transplanted with MEK1 WT or KO cells transduced with $\operatorname{Nras}^{G 12 D}(5 \%$ in protective BM WT (Figure 6A, 6C); we increased the percentage of transduced cells because NRASG12D was shown to have low leukemogenic potential [40]). Immunoblot analysis showed approximately 4.5fold NRAS overexpression in $\mathrm{GFP}^{+} \mathrm{WT}$ and $\mathrm{KO}$ cells. Overexpression was accompanied by ERK phosphorylation, slightly higher in the KO (Figure 6B). Three out of five recipients of WT HSPC transduced with $\operatorname{Nras}^{\mathrm{G} 12 \mathrm{D}}$ developed late-onset thymic lymphoma, consistent with previous reports showing that enforced expression of NRAS ${ }^{\mathrm{G} 12 \mathrm{D}}$ results in late-onset T-ALL in bone marrow transplantation assays [41, 42] (Figure 6D, $6 \mathrm{E})$. In contrast, all mice transplanted with $\mathrm{NRAS}^{\mathrm{G} 12 \mathrm{D}} \mathrm{KO}$ $\mathrm{BM}$ cells remained disease-free throughout the observation period of 200 days (Figure 6D, 6E). Thus, loss of MEK1 prevents NRAS ${ }^{\mathrm{G} 12 \mathrm{D}}$-driven leukemogenesis.

To test the impact of MEK1 ablation in leukemias involving activation of both $\mathrm{NRAS}^{\mathrm{G} 12 \mathrm{D}}$ and MYC, we

A
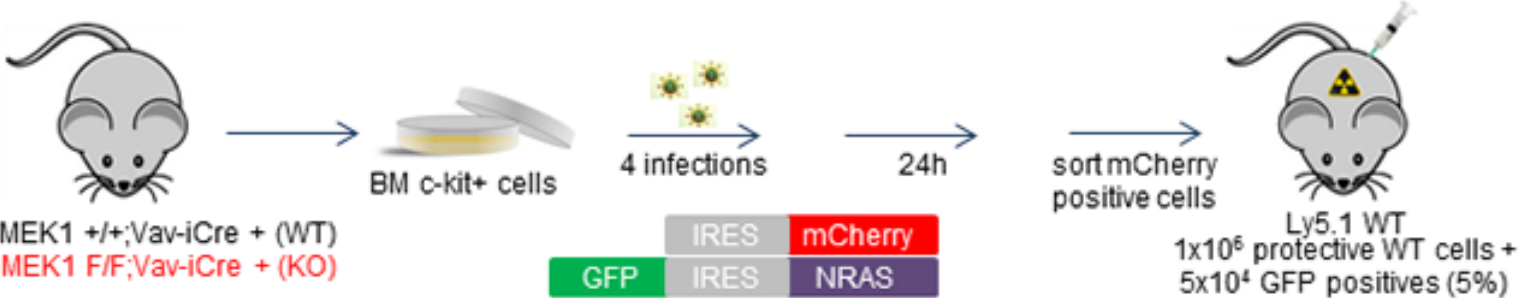

Ly5.2 MEK1 +/+;Vav-iCre + (WT)

Ly5.2 MEK1 F/F;Vav-iCre + (KO)

\begin{tabular}{|l|l|l|}
\cline { 2 - 3 } & IRES & mCherry \\
\hline GFP & IRES & NRAS \\
\hline
\end{tabular}
$5 \times 10^{4}$ GFP positives ( $\left.5 \%\right)$

B

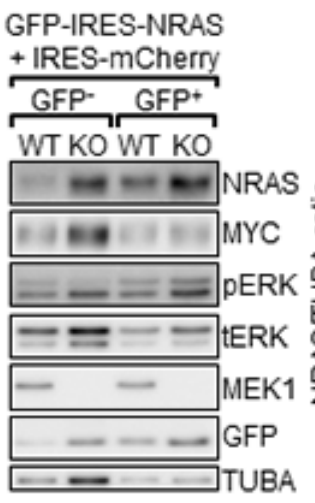

C

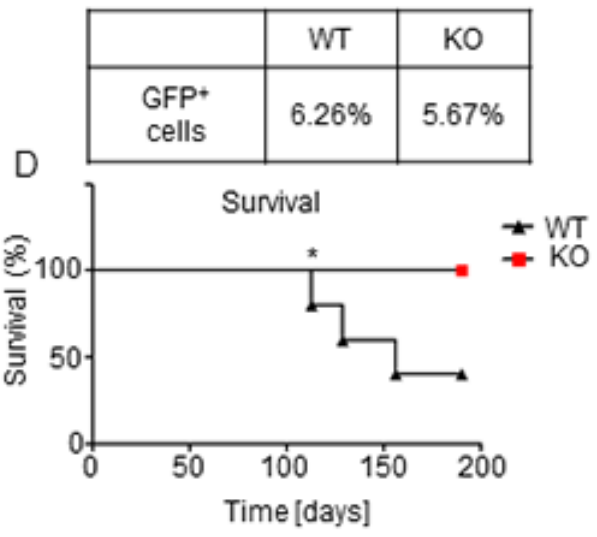

$E$

\begin{tabular}{|l|l|l|}
\hline Disease & WT & KO \\
\hline T-ALL & $3 / 5$ & $0 / 5$ \\
\hline Disease free & $2 / 5$ & $5 / 5$ \\
\hline
\end{tabular}

Figure 6: MEK1 ablation prolongs the survival of mice in a NRAS ${ }^{\text {G12D }}$-driven leukemia model. A. Schematic of experimental procedure: $\mathrm{c}-\mathrm{Kit}^{+}$-enriched $\mathrm{BM}$ cells were transduced with retroviral particles coding for the $\mathrm{Nras}^{G 12 D}$ oncogene and GFP. $24 \mathrm{~h}$ after the last infection $\mathrm{GFP}^{+}$cells were sorted, mixed with protective BM and injected in lethally irradiated WT mice $\left(5 \times 10^{4} \mathrm{WT}\right.$ or $\mathrm{KO}^{\mathrm{NRAS}} \mathrm{S}^{\mathrm{G} 12 \mathrm{D}+}$ cells in $1 \times 10^{6}$ protective WT BM per mouse). B. Efficient, equal upregulation of NRAS in transduced cells. Transduced cells were sorted for $\mathrm{GFP}^{-}$or $\mathrm{GFP}^{+}$cells and analyzed by immunoblotting. The plot represents a densitometric quantification of the immunoblots performed using ImageLab software. The data are expressed as relative band intensity adjusted to TUBA, which serves as a loading control. C. Initial transduction efficiency. D. Kaplan- Meier plot depicting the survival of recipients transplanted with WT or MEK1 KO NRAS ${ }^{\mathrm{G} 12 \mathrm{D}}$ cells. The data were analyzed using the log-rank test. $\chi 2=3.862, p=0.0494$. E. 3 out of 5 WT mice developed T-ALL. The other WT and all KO mice remained disease free. 
transplanted lethally irradiated mice with $\mathrm{Nras}^{G 12 D} / \mathrm{Myc}$ transduced cells (1\% in WT protective BM; Figure 7A, 7C). Immunoblot analysis showed comparable expression of both NRAS and CMYC in $\mathrm{GFP}^{+} / \mathrm{mCherry}^{+} \mathrm{WT}$ and $\mathrm{KO}$ cells, and increased ERK phosphorylation, slightly higher in the $\mathrm{KO}$ (Figure 7B). The recipients of MEK1 WT NRAS ${ }^{\text {G12D }} / \mathrm{MYC}^{+} \mathrm{BM}$ cells developed a rapid disease (median survival time 24 days; Figure 7D) characterized by moderate hepatomegaly and splenomegaly (Figure $7 \mathrm{E}$ ), moderate anemia, (Figure 7F), and expansion of $\mathrm{NRAS}^{\mathrm{G} 12 \mathrm{D}} / \mathrm{MYC}^{+}$cells in blood (up to $45 \%$ ), BM (up to $50 \%$ ) and spleen (up to $60 \%$; Figure $7 \mathrm{G}$ ). Similar to the MYC-driven model, FACS analysis of WT NRAS ${ }^{\mathrm{G} 12 \mathrm{D} /}$ $\mathrm{MYC}^{+}$cells revealed a broad disease spectrum (MPD-like, mixed myeloid and B-cell malignancies, as well as T-ALL in one mouse; Figure $7 \mathrm{H}$ and Supplementary Figure 2). On the other hand, mice transplanted with MEK1 KO $\mathrm{NRAS}^{\mathrm{G} 12 \mathrm{D}} / \mathrm{MYC}^{+}$cells exhibited significantly enhanced survival (mean survival time 33 day; $p$ value $=0.0483$ comparing mice receiving MEK1 WT and KO cells; Figure 7D). Moreover, recipients of MEK1 KO NRAS ${ }^{\mathrm{G} 12 \mathrm{D} /}$ $\mathrm{MYC}^{+}$cells showed exclusively myeloid disease (Figure $7 \mathrm{H}$ and Supplementary Figure 2). Additionally, in the

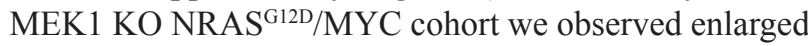
lymph nodes containing $\mathrm{Mac}^{+} \mathrm{Gr}-1^{+} \mathrm{NRAS}^{\mathrm{G} 12 \mathrm{D}} / \mathrm{MYC}^{+}$ cells (Supplementary Figure 2), reminiscent of myeloid sarcomas. Immunoblot analysis of leukemic cell lines derived from diseased mice showed variable, but comparable NRAS and MYC expression in lines derived from WT and KO animals (Figure 7I). The expression of both NRAS and CMYC was significantly higher in cells derived from T-ALL diseased WT mice, consistent with previous reports that $\mathrm{T}$ cells require stronger NRAS oncogenic signaling then myeloid cells [42]. ERK phosphorylation was slightly elevated in the KO leukemic cell lines, but the significance of this increase is limited by the different spectrum of transformed cells which could be obtained from recipients of WT and KO cells (Figure 7I). Taken together, MEK1 ablation prevented the development of NRAS ${ }^{\mathrm{G} 12 \mathrm{D}}$-driven disease, prolonged survival in NRAS ${ }^{\mathrm{G} 12 \mathrm{D}} / \mathrm{MYC}$-driven leukemia model and shifted the spectrum of the latter disease towards myeloid malignancies.

The level of expression of oncogenic NRAS is a rate-limiting factor in leukemia development. In retroviral mosaic models such as the one used here, strong NRAS $^{\mathrm{G} 12 \mathrm{D}}$ overexpression results in CMML-like MPD and AML with 3 months latency [43, 44]. In contrast, Mx-Creinducible expression of LSL-NRAS ${ }^{\mathrm{G} 12 \mathrm{D}}$ allele driven by its endogenous promoter led to late onset myeloproliferative diseases [45, 46], but did not develop acute leukemia. Similarly, mice homozygous for a hypomorphic NRAS ${ }^{\mathrm{G} 12 \mathrm{D}}$ allele do not develop tumors, while NRAS ${ }^{\mathrm{G} 12 \mathrm{D} / \mathrm{G} 12 \mathrm{D}}$ mice develop acute MPD within 3 months [42]. In further support of this, acquired uniparental disomy affecting the NRAS locus has been reported both in mouse models [46] and in patients [47], and correlates with the progression of the disease. While WT RAS has been previously reported to suppress the development of lung tumors [48] and thymic lymphomas [49], in leukemias WT NRAS lacks tumor suppressor activity, and acquired UPD serves the purpose of reaching the level of NRAS oncogenic pressure necessary for the disease progression [50].

Collectively, our data show that MEK1 is dispensable for the proliferation of human leukemia cell lines in culture or MYC-driven leukemogenesis; in contrast, MEK1 is required for the establishment of retroviral models of leukemia driven by NRAS alone or in combination with MYC. Essentially two mechanisms can be envisioned to rationalize the requirement for MEK in NRAS ${ }^{\mathrm{G} 12 \mathrm{D}}$-driven leukemogenesis. The first possibility is reduced signal flux through the MEK/ERK pathway. In other words, MEK1 might be required to obtain the full-fledged ERK activation necessary to fuel NRASdriven leukemia. In line with this hypothesis, Aoidi and colleagues have recently shown that a certain level of MEK, irrespectively of the isoform, is necessary for proper activation of ERK signaling during mouse embryonic development [51]. In an analogous manner, MEK1 ablation might reduce the pool of MEK available for ERK activation in NRAS-driven leukemias and thus adversely affect the proliferative and/or survival capacity of the leukemic cells. The importance of full-fledged pathway activation has been recently underscored by the finding that myeloid leukemogenesis driven by endogenous RAS requires high levels of signaling that can be achieved by additional mutations disabling RAS negative feedback [52]. These observations are in line with our data showing complete protection from NRAS-driven T-ALL by MEK1 ablation, and with the finding that MEK inhibitors are able to suppress the growth of NRAS G12D/G12D T-ALL cells [42].

It is also possible, however, that the reduced leukemogenic activity of NRAS ${ }^{\mathrm{G} 12 \mathrm{D}}$ and NRAS ${ }^{\mathrm{G} 12 \mathrm{D}} / \mathrm{MYC}$ expressing MEK1 KO cells might be due to too high rather than too low signal levels. In non-transformed cells, MEK1 ablation increases both ERK and AKT signaling by disabling negative feedback steps in the pathways $[14,15]$. Increased pathway activation correlates with the myeloproliferative disorder observed in the MEK1 KO mice, suggesting that MEK1 suppresses proliferation in this context. However, high levels of ERK signaling induced by oncogenic RAS have long been known to induce senescence and thus prevent transformation in culture and tumorigenesis in vivo until this failsafe mechanism is disabled [53-57]. Indeed, MEK inhibition or ERK2 silencing can bypass RAS-induced senescence in human fibroblasts and human mammary epithelial cells [58]. PI3K/AKT signaling can also induce senescence [5961], albeit to a lower degree than RAS [62], and increased AKT activation as a consequence of PTEN heterozygosity or loss can induce tumor suppression in leukemia [63, 64]. It is thus possible that MEK1 ablation, by boosting two 


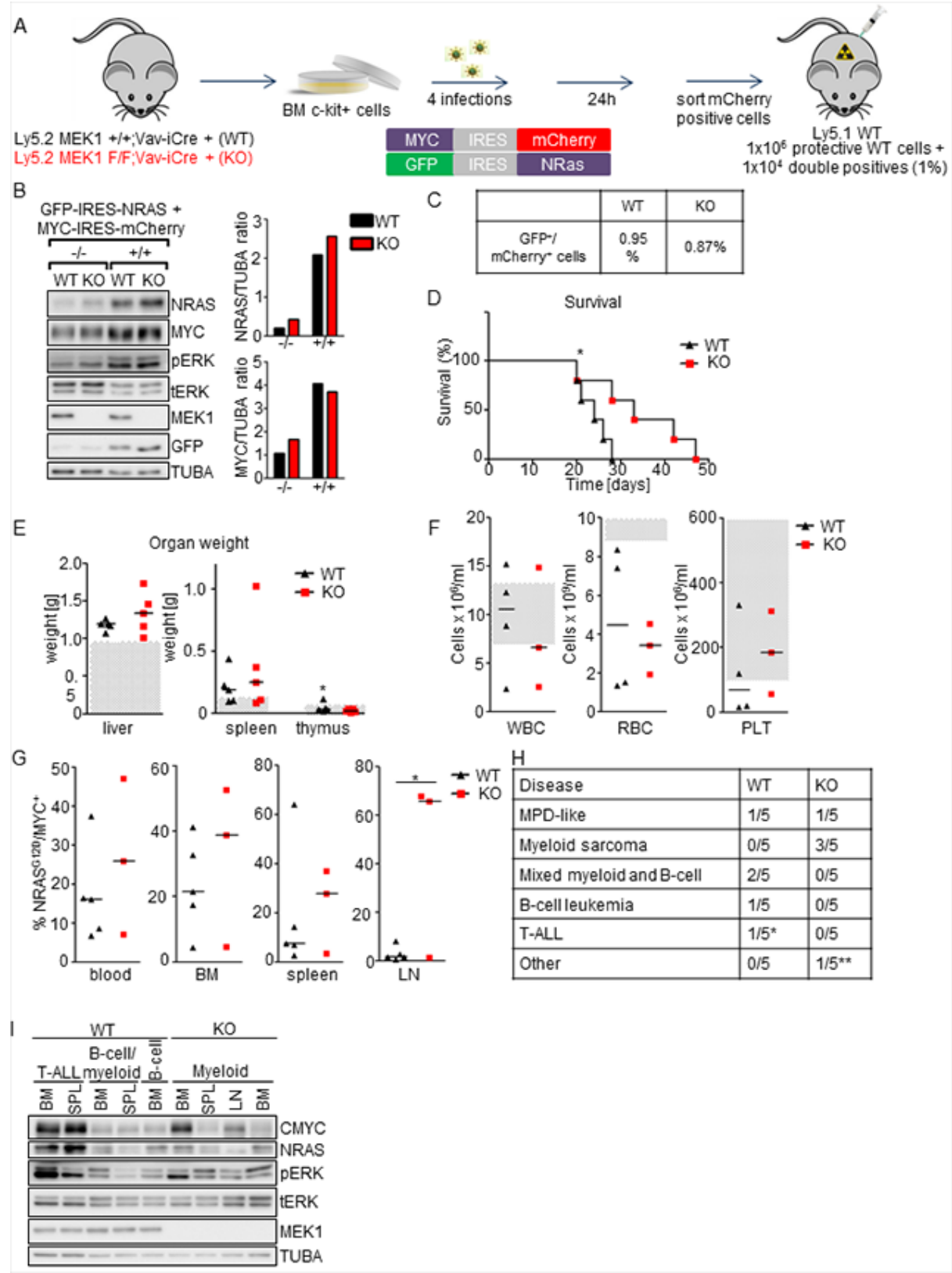

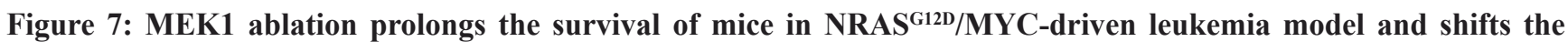

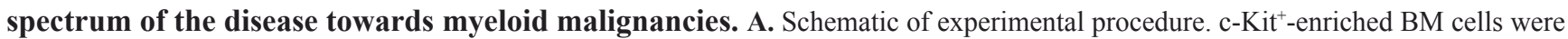
transduced with two retroviral particles coding for the $\mathrm{Nras}^{G / 2 D}$ and $M y c$ oncogenes. $24 \mathrm{~h}$ after the last infection $\mathrm{GFP} / \mathrm{mCherry}{ }^{+}$cells were sorted, mixed with protective WT BM and injected in lethally irradiated WT mice $\left(1 \times 10^{4} \mathrm{WT}\right.$ or KO NRAS ${ }^{\mathrm{G} 12 \mathrm{D}} / \mathrm{MYC}^{+}$cells in $1 \times 10^{6} \mathrm{WT}$ protective BM per mouse). B. Efficient, similar upregulation of NRAS ${ }^{\mathrm{G} 12 \mathrm{D}}$ and CMYC in transduced cells. Transduced cells were sorted for $\mathrm{GFP}^{-} / \mathrm{mCherry}^{-}(-/-)$or $\mathrm{GFP}^{+} / \mathrm{mCherry}^{+}(+/+)$cells and analyze by immunoblotting. The plots represent a densitometric quantification of the immunoblots performed using ImageLab. The data are expressed as relative band intensity adjusted to TUBA, which serve as a loading control. C. Initial transduction frequency. D. Kaplan-Meier plot depicting the survival of recipients transplanted with WT or MEK1 KO NRAS ${ }^{G 12 D} / \mathrm{MYC}^{+}$cells. The data were analyzed using the log-rank test. $\chi 2=3.900, p=0.0483$. E. Moderate hepatomegaly and splenomegaly in mice transplanted with both WT and KO NRAS ${ }^{\mathrm{G} 12 \mathrm{D}} / \mathrm{MYC}^{+}$cells. Grey boxes indicate the physiological weight range. F. Mice transplanted with either WT or KO NRAS ${ }^{\mathrm{G} 12 \mathrm{D}} / \mathrm{MYC}^{+}$cells develop a moderate anemia (RBC, red blood cells). White blood cells (WBC) and platelets (PLT) count in both cohorts shows a large variability. Grey boxes indicate the physiological range. G. Moribund animals transplanted with either WT or KO cells show expansion of NRAS ${ }^{\mathrm{G} 12 \mathrm{D}} / \mathrm{MYC}^{+}$cells in blood, BM and spleen, whereas only mice transplanted with KO NRAS/MYC ${ }^{+}$cells display infiltration of lymph nodes (LN). H. Mice transplanted with WT NRAS ${ }^{G 12 D} / M C^{+}$cells develop a broad range of diseases. In mice receiving MEK1 KO cells, disease spectrum shifts towards myeloid malignancies. The asterisk in D and J indicates $(*)$ one mouse with T-ALL, $(* *)$ the one mouse with edema, without any other symptoms of the disease. I. Immunoblot analysis of leukemic cell lines derived from hematological cancers. Tubulin A is shown as a loading control. tERK, total ERK; pERK, phosphorylated ERK. The Western blot is representative of 2 independent experiments. 
RAS downstream pathways connected to senescence, would raise the barrier to NRAS-driven leukemogenesis. In line with this, co-expression of MYC, which has been shown to suppress RAS- and RAF-induced senescence in tumorigenesis $[65,66]$, renders MEK1 KO BM cells permissive for leukemogenesis (Figure 6). While this hypothesis is attractive, it has to be noted that the pathways activated in MEK1 KO cells can cooperate to bypass senescence in prostate cancer cells [67] and in $\mathrm{KRAS}^{\mathrm{G} 12 \mathrm{D}}$ driven pancreatic tumorigenesis [62]. Finally, concurrent activation of RAF and AKT protects breast cancer cells from chemotherapy-induced senescence [68]. These observations would predict that deregulated signaling in MEK1 KO cells would counteract senescence, promoting tumorigenesis. Collectively, these reports highlight the complexity of the relationship between pathway crosstalk, signal output levels, and cell type-specific effects, illustrating the challenges the community is facing when dealing with signaling molecules as therapeutic targets [8].

In conclusion, our result show that loss of MEK1, while tumor-promoting in some contexts, can attenuate tumorigenesis in other contexts such as leukemias involving oncogenic NRAS activation. Thus, MEK1 does not act as a general tumor suppressor in leukemogenesis. Rather, its effects strongly depend on the genetic context (RAS versus MYC-driven leukemia) and on the cell type involved. Given the availability of advanced inhibitors and their efficacy in RAS-driven hematopoetic malignancies in both clinical and preclinical settings $[12,13]$, our data confirm that MEK should be further considered as a therapeutic target, in particular in combinatorial regimens with PI3K inhibitors. Previous attempts to treat patients with various advanced cancers with MEK inhibitors have been hampered by grade III-IV adverse effects of these drug, both as single agents [69] and in combination with PI3K inhibitors [70]. However, the latest phase II clinical trial with the new generation MEK inhibitor selumetinib in patients with advanced myelogenous leukemia has shown that the drug is reasonably well tolerated (adverse effects I-II grade), although it had only modest efficiency as a single agent [71]. The hope is that current efforts aimed at reducing the toxicity of MEK and PI3K or AKT inhibitors will render combination therapies feasible in the future.

\section{MATERIALS AND METHODS}

\section{Ethics statement}

The investigation has been conducted in accordance with the ethical standards and according to the Declaration of Helsinki and according to national and international guidelines. Animal experiments were authorized by the Austrian Ministry of Science and Communications, following the approval by the Ethical Committee for
Animal Experimentation (permit number: BMWF66.006/0002-II/3b/2014)

\section{Mice}

Meklfff and Mek1 fff; Sox2Cre mice have been described previously [14]. Mice were backcrossed into the pure C57BL/6 background for 10 generations to obtain pure C57BL/6 Meklff; Sox2Cre animals. Mekl ${ }^{\text {fff }}$; Vav1iCre mice were obtained by mating Meklff C57BL/6-Ly5.2 mice with Vav1-iCre transgenic animals [72] provided by Meinrad Busslinger. Syngeneic C57BL/6-Ly5.1 recipient (maintained in the IMBA/IMP animal house) were used for in vivo leukemia studies.

\section{Plasmids constructs and cloning}

Mouse Myc and $\operatorname{Nras}^{G 12 D}$ cDNA were cloned into MSCV-based retroviral vectors [73, 74] co-expressing GFP (MSCV-IRES-GFP) or mCherry (MSCV-IRESmCherry). The following vectors were generated: MSCV-MYC-IRES-GFP, MSCV-IRES-mCherry, MSCV-

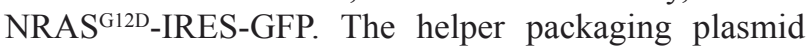
CMV-gag/pol was described previously [75].

20bp shRNAs against human MEK1 (MAP2K1 mRNA (NM_002755.3); starting position: 1361, 1918, $857,1916, \overline{2100)}$ were designed based on improved design rules [76] and cloned into microRNA stem (miR-E) in the pSIN-TRE3G-GFP-miR-E-PGK-Neo (RT3GEN) retroviral vector, as described previously [18]. A vector containing shRNA against renilla luciferase gene (Ren.713) served as control.

Guide RNA targeting human MEK1 exon 1 were designed using online CRISPR Design Tool software (http://crispr.mit.edu). The selected sequence (CGTTAACTGCAGAGCCGTCG) was designed as single strand DNA oligonucleotides containing overhangs suitable for cloning into BbsI restriction sites of pSpCas9(BB)-2A-GFP plasmid [77].

Retroviral constructs were propagated into Stbl3 E.Coli strain (NEB), cloning procedures and propagation of expression plasmids were performed in Top 10 E.Coli (Invitrogene). All constructs were verified by sequencing and purified using QIAgen Plasmid Maxi Kit.

\section{Cell culture and proliferation assays}

HL-60, K562 and THP-1 human leukemia cell lines were obtained from ATCC and cultured in RPMI1640 plus 10\% FCS and penicillin/streptomycin (all from Sigma Aldrich). K562R and THP-1R cell lines, modified to express ecotropic receptor and rtTA3 as described previously[17], were grown under the same conditions as the parental lines with addition of puromycin (Sigma 
Aldrich) $(1.5 \mu \mathrm{g} / \mathrm{ml}$ or $0.75 \mu \mathrm{g} / \mathrm{ml}$, respectively). To generate MEK1 knock-down (KD) cell lines, K562R and THP-1R cells were transduced with RT3GEN based retroviral pseudoparticles supplemented with $4 \mu \mathrm{g} / \mathrm{ml}$ polybrene and spinfected for $30 \mathrm{~min}$ at $450 \mathrm{xg}, 37^{\circ} \mathrm{C}$. The infection was repeated after 5, 10 and $24 \mathrm{hr}$. Transduced cells were selected for two weeks in $1 \mathrm{mg} / \mathrm{ml} \mathrm{G} 418$ (Invitrogene). Positively selected cells were treated with 1 $\mu \mathrm{g} / \mathrm{ml}$ of doxycycline for $72 \mathrm{hr}$ to induce expression of the GFP-miRE cassette and thus MEK1 knock-down.

To generate MEK1 knock-out cells, HL-60 cells were transiently nucleofected with pSpCas9(BB)-2AGFP containing sgRNA against $M E K 1$ exon1 using Amaxa ${ }^{\circledR}$ Cell Line Nucleofector ${ }^{\circledR}$ Kit V (Lonza), according to the manufacturer's protocol. Viable, $\mathrm{GFP}^{+}$cells were single-cell sorted into 96-well plate and cultured for three weeks. The plates were screened by light microscopy for the presence of growing clones, which were further expanded. MEK1 KO clones were identified by immunoblotting and the knock-out was further confirmed by sequencing of the Cas9-targeted site in the MEK1 gene PCR amplified using primers for hMEK1exon1 (forward: GGTTGGTTGAGAGAGAGAGAGG; reverse: GCTGGTCTCAAAAGCACAGATG).

To monitor proliferation, THP-1R MEK1 KD and Ren ctr cell lines were seeded in 6 wells of a 96-well plate at the concentration of $2 \times 10^{4}$ cells/well in $200 \mu \mathrm{l}$ of medium. Half of the wells were treated with $1 \mathrm{ug} / \mathrm{ml}$ of doxycycline (triplicates for each condition). After $72 \mathrm{hr}$ incubation, the cells were resuspended thoroughly and 50 $\mu \mathrm{l}$ of the cell suspension were transferred to a new plate, fed with additional $50 \mathrm{ul}$ medium and cultured for an additional 4 days. The cells were allowed to metabolize MTT $\left(0.6 \mathrm{mg} / \mathrm{ml}\right.$; Sigma Aldrich) for $2 \mathrm{hr}$ at $37^{\circ} \mathrm{C}, 5 \% \mathrm{CO}_{2}$. After incubation the formazan crystals were solubilized with $110 \mu \mathrm{l}$ of acidified isopropanol $(0.04 \mathrm{M} \mathrm{HCl}$ in absolute isopropanol) and the absorbance was measured at $595 \mathrm{~nm}$ with a Victor3V plate reader (Perkin Elmer).

HL-60 ctr and MEK1 KO clones were seeded at the concentration of $1 \times 10^{5}$ cells $/ \mathrm{ml}$, cultured for 24,48 or 72 hr, at $37^{\circ} \mathrm{C}, 5 \% \mathrm{CO}_{2}$ and counted. The experiment was repeated 4 times.

For competition assays, K562R cells, K562R MEK KD (MEK1.1361, MEK1.1918, MEK1.857, MEK1.1916, MEK1.2100) and K562 Ren.713 ctr cells were pretreated with $1 \mu \mathrm{g} / \mathrm{ml}$ of doxycycline for $72 \mathrm{hr}$. K562R MEK1 $\mathrm{KD}$ or Ren ctr cells (all expressing GFP-miR-E after doxycycline induction) were mixed 1:1 with K562R cells (no GFP-miR-E cassette). The cell mixture was seeded at the final concentration of $1 \times 10^{5}$ cells $/ \mathrm{ml}$ in $2 \mathrm{ml}$ of RPMI plus 0.5 or $10 \%$ FCS and penicillin/streptomycin. The cells were incubated at $37^{\circ} \mathrm{C}, 5 \% \mathrm{CO}_{2}$ and passaged every 2-3 days for a period of 3 weeks. The percentage of $\mathrm{GFP}^{+}$cells in the initial inoculum and after each passage was determined by flow cytometry (FACSCalibur, BD Biosystems).

\section{Generation of high-titer retroviral pseudoparticles}

The Platinum-E packaging cell line (Cell BioLabs) was maintained in DMEM plus 10\% FCS and penicillin/ streptomycin (all from Sigma Aldrich).

Ecotropic retroviral pseudoparticles were produced in Platinum-E cells, essentially as previously described [78]. Briefly, $8-10 \mathrm{hr}$ before transfection, a $90 \%$ confluent $\varnothing 10 \mathrm{~cm}$ plate of Platinum-E cells was split 1:2. Packaging cells were transfected using a standard calcium phosphate co-precipitation method. After $12 \mathrm{hr}$, the transfection medium was exchanged. After $12 \mathrm{hr}$ incubation, the medium was replaced with $5 \mathrm{ml}$ of medium optimal for transduced cells. Retrovirus-containing supernatants were harvested $36-48 \mathrm{hr}$ after the transfection, filtered through $0.45-\mu \mathrm{m}$ syringe filter and used freshly to transduce target cells.

\section{Bone marrow cell transduction}

Bone marrow (BM) cells were isolated from femurs, tibias and hip bones of 6-9 weeks old mice using a crushing method. Red blood cells (RBCs) were lysed for 2 $\mathrm{min}$ at $\mathrm{RT}$ in $2 \mathrm{ml}$ of $\mathrm{RBC}$ lysis buffer. Bone marrow stem and progenitor cells enrichment (BM HSPCs; enrichment for $\mathrm{CKit}^{+}$) was performed using mouse CD117 Microbeads (Miltenyi biotec) according to the manufacturer's protocol. $1 \times 10^{6} \mathrm{cKit}^{+} \mathrm{BM}$ cells were seeded in 6-well plate in 1.2 $\mathrm{ml}$ of StemPro-34 SFM medium (Gibco) supplemented with 1X StemPro-Nutrient Supplement, 2 mM Glutamax (Gibco), penicillin/streptomycin and a cytokine cocktail optimized for expansion of HSPCs: $2 \mathrm{ng} / \mathrm{ml} \mathrm{mrIL-3} \mathrm{(R \& D}$ Systems), $2 \mathrm{ng} / \mathrm{ml} \mathrm{hrIL-6}$ (eBioscence), $10 \mathrm{ng} / \mathrm{ml} \mathrm{mrSCF}$ (R\&D Systems), $2 \mathrm{ng} / \mathrm{ml} \mathrm{mrTPO}$ (R\&D Systems), $10 \mathrm{ng} /$ $\mathrm{ml}$ mouse recombinant Flt-3 ligand (R\&D Systems) [31]. After $18 \mathrm{hr}$ of pre-culture, BM HSPCs were transduced with $1 \mathrm{ml}$ of MSCV-based retrovirus-containing supernatants supplemented with $4 \mu \mathrm{g} / \mathrm{ml}$ polybrene (Sigma Aldrich), $1 \mathrm{mM}$ dNTPs (Thermo Scientific) and cytokines, and spinfected for $30 \mathrm{~min}$ at $450 \mathrm{xg}$, at $37^{\circ} \mathrm{C}$. The infection was repeated after 5, 10 and $24 \mathrm{hr}$. $24 \mathrm{hr}$ after the last infection, BM cells were harvested, washed twice in cold PBS and used immediately for further in vivo or in vitro experiments.

\section{Colony forming assay}

Transduced BM cells from Mek $1^{f /+}$ (WT) or Mek $1^{f f f}$; Sox $2 \mathrm{Cre}(\mathrm{KO})$ were stained with Fixable Viability Dye eFluor 450 (eBioscience) and for each condition $6 \times 10^{3}$ viable, $\mathrm{GFP}^{+}$cells were sorted on FACSAria- IIIu LSR (BD Bioscience) directly into $3.3 \mathrm{ml}$ of MethoCult M3434 semisolid media (StemCell Technologies). Cells were seeded in duplicates in 6-well plates $\left(2 \times 10^{3}\right.$ cell/well in 
$1.1 \mathrm{ml}$ of medium) and cultured for 10 days at $37^{\circ} \mathrm{C}, 5 \%$ $\mathrm{CO} 2$. Following the incubation, the number of colonies was determined. The cells were harvested, counted and replated in fresh MethoCult M3434 $\left(2 \times 10^{3}\right.$ cell/well in $1.1 \mathrm{ml}$ of medium). Counting and replating was repeated 3 times.

\section{In vivo leukemia studies}

BM cells from 6-9 week old $\mathrm{Mek1}^{+/{ }^{+}}$; Vav1iCre ${ }^{+}(\mathrm{WT})$ or Meklff; $V a v 1-i C r e^{+}(\mathrm{KO})$ mice were cotransduced with the following retroviral pseudoparticles: a) MSCV-MYC-IRES-mCherry and MSCVGFP; b) MSCV-GFP-IRES-NRAS ${ }^{\mathrm{G} 12 \mathrm{D}}$ and MSCV-mCherry; c) MSCV-MYC-IRES-mCherry and MSCV-GFP-IRES$\mathrm{NRAS}^{\mathrm{G} 12 \mathrm{D}}$. Viable, transduced cells were sorted on FACSAria-IIIu LSR and either used for immunoblot analysis or mixed with wild type (WT) protective BM. 8-12 week old female C57BL/6-Ly5.1 recipients were lethally irradiated with 2 doses of 5.5 Gy (first in the previous evening and secondly directly before the injections). Mice were injected intravenously via the tail vein with $1 \times 10^{6}$ protective $\mathrm{BM}$ per mouse containing a percentage of transduced cells adjusted to result in disease kinetics enabling the detection of a phenotype. Mice were monitored daily for disease symptoms and moribund animals were sacrificed with $\mathrm{CO}_{2}$. Primary and secondary hematopoietic organs (BM, spleen, blood, thymus and lymph nodes) were harvested, the cells isolated in IMDM plus $2 \% \mathrm{FCS}$ and penicillin/streptomycin, and further analyzed by FACS. The log-rank test was used to evaluate the significance of the difference in survival. A p value $\leq$ 0.05 is considered statistically significant.

\section{Blood analysis and flow cytometry}

Peripheral blood counts were acquired using the V-Sight hematology analyzer (A. Menarini Diagnostic). RBCs were lysed for 5 min at RT in RBC lysis buffer. Freshly isolated BM, spleen, thymus, lymph node, and white blood cells were stained with Fixable Viability Dye eFluor 780 (eBioscience), blocked for 10 minutes with TruStain FcX anti-mouse CD16/32 (BioLegends) and stained for 30 minutes in brilliant stain buffer (BD Bioscience) with antibodies against Ly5.1-PerCP-Cy5.5 (eBioscence \#45-0453), Ly5.2-V500 (BD Bioscence 562129), CD19-BV786 (BD Bioscience \#563333), CD3e-APC (BD Bioscence \#553066), Mac1-BV650 (BD Bioscience \#563402), Gr-1-APC (eBioscience \#17-5931) and Ter119-BV421 (BD Bioscence 563998). Cells were analyzed by FACSFortessa (BD BioScience) and FlowJo software.

\section{Whole cell lysates and immunoblotting}

Leukemic cells lines were harvested by centrifugation at $300 \mathrm{xg}$ for 5 minutes, lysed in buffer containing $20 \mathrm{mM}$ TrisHCl pH 7.4, $137 \mathrm{mM} \mathrm{NaCl}, 1 \mathrm{mM}$ $\mathrm{CaCl} 2,1 \mathrm{mM} \mathrm{MgCl} 2,1 \% \mathrm{NP}-40,1 \mathrm{mM} \mathrm{Na} 3 \mathrm{VO} 4,50 \mathrm{mM}$ $\mathrm{NaF}, 2 \mathrm{mM}$ PMSF and protease inhibitor cocktail (Roche). Transduced, sorted BM cell were lysed in 1X Laemmli buffer supplemented with $1 \mathrm{mM} \mathrm{Na} 3 \mathrm{VO} 4,50 \mathrm{mM} \mathrm{NaF}$, $2 \mathrm{mM}$ PMSF and protease inhibitor cocktail. The total protein concentration was measured using Pierce BCA Protein Assay Kit (Thermo Scientific). 5-20 $\mu \mathrm{g}$ of protein were analyzed on $10 \%$ SDS-PAGE gels. The proteins were transferred to ImmobilonP PVDF membranes (Milipore) activated in ethanol, by overnight wet blotting in Tris-Glycine. The membranes were blocked for $1 \mathrm{hr}$ in $5 \%$ milk in TBS-T, and incubated for $1 \mathrm{hr}$ at room temperature or overnight at $4{ }^{\circ} \mathrm{C}$ with primary antibodies (MEK1 (Cell Signaling \#2352), MEK2 (BD Transduction Laboratories \#610236), GFP (Roche \#11814460001), GAPDH (Milipore \#abs16), TUBA (Sigma \#T9026), tERK (Cell Signaling \#9102), pERK(Cell Signaling \#9101), CMYC (Abcam \#ab32072) and NRAS (Santa Cruz \#sc-31) and developed using SuperSignal West Pico/ Femto Chemiluminescent Substrate (Thermo Scientific), Amersham Hyperfilm (Ge Healthcare) and CURIX 60 processor (Agfa) or ChemiDoc Touch Imaging System (Bio-Rad). Densitometric quantification of immunoblots was performed using ImageLab software.

\section{ACKNOWLEDGMENTS}

We thank Gijs Versteeg for helpful discussions and Clemens Bogner, Karin Ehrenreiter and the animal facility for excellent technical assistance. The work was supported by FWF grant P26303-B20 to M.B.

\section{CONFLICTS OF INTEREST}

The authors declare that they have no conflict of interest.

\section{REFERENCES}

1. Siegel RL, Miller KD and Jemal A. Cancer statistics, 2016. CA Cancer J Clin. 2016; 66:7-30.

2. Corces-Zimmerman MR and Majeti R. Pre-leukemic evolution of hematopoietic stem cells: the importance of early mutations in leukemogenesis. Leukemia. 2014; 28:2276-2282.

3. Maurer G, Tarkowski B and Baccarini M. Raf kinases in cancer-roles and therapeutic opportunities. Oncogene. 2011; 30:3477-3488.

4. Tartaglia M and Gelb BD. Disorders of dysregulated signal traffic through the RAS-MAPK pathway: phenotypic 
spectrum and molecular mechanisms. Ann N Y Acad Sci. 2010; 1214:99-121.

5. Chung E and Kondo M. Role of Ras/Raf/MEK/ERK signaling in physiological hematopoiesis and leukemia development. Immunol Res. 2011; 49:248-268.

6. Staser K, Park SJ, Rhodes SD, Zeng Y, He YZ, Shew MA, Gehlhausen JR, Cerabona D, Menon K, Chen S, Sun Z, Yuan J, Ingram DA, Nalepa G, Yang FC and Clapp DW. Normal hematopoiesis and neurofibromin-deficient myeloproliferative disease require Erk. J Clin Invest. 2013; 123:329-334.

7. Al-Kali A, Quintas-Cardama A, Luthra R, Bueso-Ramos C, Pierce S, Kadia T, Borthakur G, Estrov Z, Jabbour E, Faderl S, Ravandi F, Cortes J, Tefferi A, Kantarjian H and Garcia-Manero G. Prognostic impact of RAS mutations in patients with myelodysplastic syndrome. Am J Hematol. 2013; 88:365-369.

8. Steelman LS, Franklin RA, Abrams SL, Chappell W, Kempf CR, Basecke J, Stivala F, Donia M, Fagone P, Nicoletti F, Libra M, Ruvolo P, Ruvolo V, Evangelisti C, Martelli AM and McCubrey JA. Roles of the Ras/Raf/ MEK/ERK pathway in leukemia therapy. Leukemia. 2011; 25:1080-1094.

9. Ricciardi MR, McQueen T, Chism D, Milella M, Estey E, Kaldjian E, Sebolt-Leopold J, Konopleva M and Andreeff M. Quantitative single cell determination of ERK phosphorylation and regulation in relapsed and refractory primary acute myeloid leukemia. Leukemia. 2005; 19:15431549.

10. Gregorj C, Ricciardi MR, Petrucci MT, Scerpa MC, De Cave F, Fazi P, Vignetti M, Vitale A, Mancini M, Cimino G, Palmieri S, Di Raimondo F, Specchia G, Fabbiano F, Cantore N, Mosna F, et al. ERK1/2 phosphorylation is an independent predictor of complete remission in newly diagnosed adult acute lymphoblastic leukemia. Blood. 2007; 109:5473-5476.

11. Caunt CJ, Sale MJ, Smith PD and Cook SJ. MEK1 and MEK2 inhibitors and cancer therapy: the long and winding road. Nat Rev Cancer. 2015; 15:577-592.

12. Irving JA. Towards an understanding of the biology and targeted treatment of paediatric relapsed acute lymphoblastic leukaemia. Br J Haematol. 2016; 172:655666.

13. Knight $\mathrm{T}$ and Irving JA. Ras/Raf/MEK/ERK Pathway Activation in Childhood Acute Lymphoblastic Leukemia and Its Therapeutic Targeting. Frontiers in oncology. 2014; 4:160.

14. Catalanotti F, Reyes G, Jesenberger V, Galabova-Kovacs G, de Matos Simoes R, Carugo O and Baccarini M. A Mek1Mek2 heterodimer determines the strength and duration of the Erk signal. Nat Struct Mol Biol. 2009; 16:294-303.

15. Zmajkovicova $\mathrm{K}$, Jesenberger $\mathrm{V}$, Catalanotti $\mathrm{F}$, Baumgartner C, Reyes $\mathrm{G}$ and Baccarini M. MEK1 is required for PTEN membrane recruitment, AKT regulation, and the maintenance of peripheral tolerance. Mol Cell. 2013; 50:43-55.

16. Bric A, Miething C, Bialucha CU, Scuoppo C, Zender L, Krasnitz A, Xuan Z, Zuber J, Wigler M, Hicks J, McCombie RW, Hemann MT, Hannon GJ, Powers S and Lowe SW. Functional identification of tumor-suppressor genes through an in vivo RNA interference screen in a mouse lymphoma model. Cancer Cell. 2009; 16:324-335.

17. Zuber J, Shi J, Wang E, Rappaport AR, Herrmann H, Sison EA, Magoon D, Qi J, Blatt K, Wunderlich M, Taylor MJ, Johns C, Chicas A, Mulloy JC, Kogan SC, Brown P, et al. RNAi screen identifies Brd4 as a therapeutic target in acute myeloid leukaemia. Nature. 2011; 478:524-528.

18. Fellmann C, Hoffmann T, Sridhar V, Hopfgartner B, Muhar M, Roth M, Lai DY, Barbosa IA, Kwon JS, Guan Y, Sinha $\mathrm{N}$ and Zuber J. An optimized microRNA backbone for effective single-copy RNAi. Cell Rep. 2013; 5:1704-1713.

19. Deininger MW, Goldman JM and Melo JV. The molecular biology of chronic myeloid leukemia. Blood. 2000; 96:3343-3356.

20. Goldman JM and Melo JV. Chronic Myeloid Leukemia Advances in Biology and New Approaches to Treatment. N Engl J Med. 2003; 349:1451-1464.

21. Drexler HG, MacLeod RA, Borkhardt A and Janssen JW. Recurrent chromosomal translocations and fusion genes in leukemia-lymphoma cell lines. Leukemia. 1995; 9:480-500.

22. Janssen JW, Steenvoorden AC, Lyons J, Anger B, Bohlke JU, Bos JL, Seliger $\mathrm{H}$ and Bartram CR. RAS gene mutations in acute and chronic myelocytic leukemias, chronic myeloproliferative disorders, and myelodysplastic syndromes. Proc Natl Acad Sci U S A. 1987; 84:9228-9232.

23. Kim WI, Matise I, Diers MD and Largaespada DA. RAS oncogene suppression induces apoptosis followed by more differentiated and less myelosuppressive disease upon relapse of acute myeloid leukemia. Blood. 2009; 113:10861096.

24. Nakanishi H, Nakamura T, Canaani $E$ and Croce CM. ALL1 fusion proteins induce deregulation of EphA7 and ERK phosphorylation in human acute leukemias. Proc Natl Acad Sci U S A. 2007; 104:14442-14447.

25. Bolukbasi MF, Gupta A and Wolfe SA. Creating and evaluating accurate CRISPR-Cas9 scalpels for genomic surgery. Nat Meth. 2016; 13:41-50.

26. Birnie GD. The HL60 cell line: a model system for studying human myeloid cell differentiation. Br J Cancer Suppl. 1988; 9:41-45.

27. Bouaoun L, Sonkin D, Ardin M, Hollstein M, Byrnes G, Zavadil J and Olivier M. TP53 Variations in Human Cancers: New Lessons from the IARC TP53 Database and Genomics Data. Human mutation. 2016.

28. Horton SJ and Huntly BJP. Recent advances in acute myeloid leukemia stem cell biology. Haematologica. 2012; 97:966-974. 
29. Huntly BJP and Gilliland DG. Cancer biology: Summing up cancer stem cells. Nature. 2005; 435:1169-1170.

30. Woll Petter S, Kjällquist U, Chowdhury O, Doolittle H, Wedge David C, Thongjuea S, Erlandsson R, Ngara M, Anderson K, Deng Q, Mead Adam J, Stenson L, Giustacchini A, Duarte S, Giannoulatou E, Taylor S, et al. Myelodysplastic Syndromes Are Propagated by Rare and Distinct Human Cancer Stem Cells In Vivo. Cancer Cell. 2014; 25:794-808.

31. Rathinam C, Matesic LE and Flavell RA. The E3 ligase Itch is a negative regulator of the homeostasis and function of hematopoietic stem cells. Nat Immunol. 2011; 12:399-407.

32. Zhang H, Duan LX, Dornadula G and Pomerantz RJ. Increasing transduction efficiency of recombinant murine retrovirus vectors by initiation of endogenous reverse transcription: potential utility for genetic therapies. J Virol. 1995; 69:3929-3932.

33. Kawagoe H, Kandilci A, Kranenburg TA and Grosveld GC. Overexpression of N-Myc rapidly causes acute myeloid leukemia in mice. Cancer Res. 2007; 67:10677-10685.

34. Wilson A, Murphy MJ, Oskarsson T, Kaloulis K, Bettess MD, Oser GM, Pasche AC, Knabenhans C, Macdonald HR and Trumpp A. c-Myc controls the balance between hematopoietic stem cell self-renewal and differentiation. Genes Dev. 2004; 18:2747-2763.

35. Luo H, Li Q, O'Neal J, Kreisel F, Le Beau MM and Tomasson MH. c-Myc rapidly induces acute myeloid leukemia in mice without evidence of lymphoma-associated antiapoptotic mutations. Blood. 2005; 106:2452-2461.

36. Hemann MT, Bric A, Teruya-Feldstein J, Herbst A, Nilsson JA, Cordon-Cardo C, Cleveland JL, Tansey WP and Lowe SW. Evasion of the p53 tumour surveillance network by tumour-derived MYC mutants. Nature. 2005; 436:807-811.

37. Network TCGAR. Genomic and Epigenomic Landscapes of Adult De Novo Acute Myeloid Leukemia. N Engl J Med. 2013; 368:2059-2074.

38. Caye A, Strullu M, Guidez F, Cassinat B, Gazal S, Fenneteau O, Lainey E, Nouri K, Nakhaei-Rad S, Dvorsky R, Lachenaud J, Pereira S, Vivent J, Verger E, Vidaud D, Galambrun C, et al. Juvenile myelomonocytic leukemia displays mutations in components of the RAS pathway and the PRC2 network. Nat Genet. 2015; 47:1334-1340.

39. Andersson AK, Ma J, Wang J, Chen X, Gedman AL, Dang J, Nakitandwe J, Holmfeldt L, Parker M, Easton J, Huether R, Kriwacki R, Rusch M, Wu G, Li Y, Mulder H, et al. The landscape of somatic mutations in infant MLL-rearranged acute lymphoblastic leukemias. Nat Genet. 2015; 47:330337.

40. Parikh C and Ren R. (2008). Mouse Model for NRASInduced Leukemogenesis. Methods in Enzymology: Academic Press, pp. 15-24.

41. Ono R, Kumagai H, Nakajima H, Hishiya A, Taki T, Horikawa K, Takatsu K, Satoh T, Hayashi Y, Kitamura
T and Nosaka T. Mixed-lineage-leukemia (MLL) fusion protein collaborates with Ras to induce acute leukemia through aberrant Hox expression and Raf activation. Leukemia. 2009; 23:2197-2209.

42. Wang J, Liu Y, Li Z, Wang Z, Tan LX, Ryu MJ, Meline B, Du J, Young KH, Ranheim E, Chang Q and Zhang J. Endogenous oncogenic Nras mutation initiates hematopoietic malignancies in a dose- and cell typedependent manner. Blood. 2011; 118:368-379.

43. Parikh C, Subrahmanyam R and Ren R. Oncogenic NRAS rapidly and efficiently induces CMML- and AML-like diseases in mice. Blood. 2006; 108:2349-2357.

44. MacKenzie KL, Dolnikov A, Millington M, Shounan Y and Symonds G. Mutant N-ras induces myeloproliferative disorders and apoptosis in bone marrow repopulated mice. Blood. 1999; 93:2043-2056.

45. Li Q, Haigis KM, McDaniel A, Harding-Theobald E, Kogan SC, Akagi K, Wong JC, Braun BS, Wolff L, Jacks T and Shannon K. Hematopoiesis and leukemogenesis in mice expressing oncogenic NrasG12D from the endogenous locus. Blood. 2011; 117:2022-2032.

46. Wang J, Liu Y, Li Z, Du J, Ryu MJ, Taylor PR, Fleming $\mathrm{MD}$, Young $\mathrm{KH}$, Pitot $\mathrm{H}$ and Zhang J. Endogenous oncogenic Nras mutation promotes aberrant GM-CSF signaling in granulocytic/monocytic precursors in a murine model of chronic myelomonocytic leukemia. Blood. 2010; 116:5991-6002.

47. Dunbar AJ, Gondek LP, O'Keefe CL, Makishima H, Rataul MS, Szpurka H, Sekeres MA, Wang XF, McDevitt MA and Maciejewski JP. 250K single nucleotide polymorphism array karyotyping identifies acquired uniparental disomy and homozygous mutations, including novel missense substitutions of c-Cbl, in myeloid malignancies. Cancer Res. 2008; 68:10349-10357.

48. Zhang Z, Wang Y, Vikis HG, Johnson L, Liu G, Li J, Anderson MW, Sills RC, Hong HL, Devereux TR, Jacks T, Guan KL and You M. Wildtype Kras2 can inhibit lung carcinogenesis in mice. Nat Genet. 2001; 29:25-33.

49. Diaz R, Ahn D, Lopez-Barcons L, Malumbres M, Perez de Castro I, Lue J, Ferrer-Miralles N, Mangues R, Tsong J, Garcia R, Perez-Soler R and Pellicer A. The N-ras protooncogene can suppress the malignant phenotype in the presence or absence of its oncogene. Cancer Res. 2002; 62:4514-4518.

50. Xu J, Haigis KM, Firestone AJ, McNerney ME, Li Q, Davis E, Chen SC, Nakitandwe J, Downing J, Jacks T, Le Beau MM and Shannon K. Dominant role of oncogene dosage and absence of tumor suppressor activity in Nras-driven hematopoietic transformation. Cancer Discov. 2013; 3:9931001.

51. Aoidi R, Maltais A and Charron J. Functional redundancy of the kinases MEK1 and MEK2: Rescue of the Mek1 mutant phenotype by Mek2 knock-in reveals a protein threshold effect. Sci Signal. 2016; 9:ra9. 
52. Zhao Z, Chen CC, Rillahan CD, Shen R, Kitzing $T$, McNerney ME, Diaz-Flores E, Zuber J, Shannon K, Le Beau MM, Spector MS, Kogan SC and Lowe SW. Cooperative loss of RAS feedback regulation drives myeloid leukemogenesis. Nat Genet. 2015; 47:539-543.

53. Lin AW, Barradas M, Stone JC, van Aelst L, Serrano M and Lowe SW. Premature senescence involving p53 and p16 is activated in response to constitutive MEK/MAPK mitogenic signaling. Genes Dev. 1998; 12:3008-3019.

54. Zhu J, Woods D, McMahon M and Bishop JM. Senescence of human fibroblasts induced by oncogenic Raf. Genes Dev. 1998; 12:2997-3007.

55. Bennecke M, Kriegl L, Bajbouj M, Retzlaff K, Robine S, Jung A, Arkan MC, Kirchner T and Greten FR. Ink4a/ Arf and oncogene-induced senescence prevent tumor progression during alternative colorectal tumorigenesis. Cancer Cell. 2010; 18:135-146.

56. Wang Z, Liu Y, Takahashi M, Van Hook K, KampaSchittenhelm KM, Sheppard BC, Sears RC, Stork PJS and Lopez CD. N terminus of ASPP2 binds to Ras and enhances Ras/Raf/MEK/ERK activation to promote oncogeneinduced senescence. Proceedings of the National Academy of Sciences. 2013; 110:312-317.

57. Sarkisian CJ, Keister BA, Stairs DB, Boxer RB, Moody SE and Chodosh LA. Dose-dependent oncogene-induced senescence in vivo and its evasion during mammary tumorigenesis. Nat Cell Biol. 2007; 9:493-505.

58. Deschenes-Simard X, Gaumont-Leclerc MF, Bourdeau V, Lessard F, Moiseeva O, Forest V, Igelmann S, Mallette FA, Saba-El-Leil MK, Meloche S, Saad F, Mes-Masson AM and Ferbeyre G. Tumor suppressor activity of the ERK/MAPK pathway by promoting selective protein degradation. Genes Dev. 2013; 27:900-915.

59. Nogueira V, Park Y, Chen CC, Xu PZ, Chen ML, Tonic $\mathrm{I}$, Unterman $\mathrm{T}$ and Hay N. Akt determines replicative senescence and oxidative or oncogenic premature senescence and sensitizes cells to oxidative apoptosis. Cancer Cell. 2008; 14:458-470.

60. Lee JJ, Kim BC, Park MJ, Lee YS, Kim YN, Lee BL and Lee JS. PTEN status switches cell fate between premature senescence and apoptosis in glioma exposed to ionizing radiation. Cell Death Differ. 2011; 18:666-677.

61. Astle MV, Hannan KM, Ng PY, Lee RS, George AJ, Hsu AK, Haupt Y, Hannan RD and Pearson RB. AKT induces senescence in human cells via mTORC1 and p53 in the absence of DNA damage: implications for targeting mTOR during malignancy. Oncogene. 2012; 31:1949-1962.

62. Kennedy AL, Morton JP, Manoharan I, Nelson DM, Jamieson NB, Pawlikowski JS, McBryan T, Doyle B, McKay C, Oien KA, Enders GH, Zhang R, Sansom OJ and Adams PD. Activation of the PIK3CA/AKT pathway suppresses senescence induced by an activated RAS oncogene to promote tumorigenesis. Mol Cell. 2011; 42:3649.
63. Lee JY, Nakada D, Yilmaz OH, Tothova Z, Joseph NM, Lim MS, Gilliland DG and Morrison SJ. mTOR activation induces tumor suppressors that inhibit leukemogenesis and deplete hematopoietic stem cells after Pten deletion. Cell Stem Cell. 2010; 7:593-605.

64. Yilmaz OH, Valdez R, Theisen BK, Guo W, Ferguson DO, $\mathrm{Wu} \mathrm{H}$ and Morrison SJ. Pten dependence distinguishes haematopoietic stem cells from leukaemia-initiating cells. Nature. 2006; 441:475-482.

65. Inoue S, Hao Z, Elia AJ, Cescon D, Zhou L, Silvester J, Snow B, Harris IS, Sasaki M, Li WY, Itsumi M, Yamamoto K, Ueda T, Dominguez-Brauer C, Gorrini C, Chio, II, et al. Mule/Huwe1/Arf-BP1 suppresses Ras-driven tumorigenesis by preventing c-Myc/Miz1-mediated down-regulation of p21 and p15. Genes Dev. 2013; 27:1101-1114.

66. Tabor V, Bocci M, Alikhani N, Kuiper R and Larsson LG. MYC synergizes with activated BRAFV600E in mouse lung tumor development by suppressing senescence. Cancer Res. 2014; 74:4222-4229.

67. Ahmad I, Patel R, Singh LB, Nixon C, Seywright M, Barnetson RJ, Brunton VG, Muller WJ, Edwards J, Sansom OJ and Leung HY. HER2 overcomes PTEN (loss)-induced senescence to cause aggressive prostate cancer. Proc Natl Acad Sci U S A. 2011; 108:16392-16397.

68. Taylor JR, Lehmann BD, Chappell WH, Abrams SL, Steelman LS and McCubrey JA. Cooperative effects of Akt-1 and Raf-1 on the induction of cellular senescence in doxorubicin or tamoxifen treated breast cancer cells. Oncotarget. 2011; 2:610-626. doi:10.18632/oncotarget.315.

69. LoRusso PM, Krishnamurthi SS, Rinehart JJ, Nabell LM, Malburg L, Chapman PB, DePrimo SE, Bentivegna S, Wilner KD, Tan W and Ricart AD. Phase I Pharmacokinetic and Pharmacodynamic Study of the Oral MAPK/ERK Kinase Inhibitor PD-0325901 in Patients with Advanced Cancers. Clinical Cancer Research. 2010; 16:1924-1937.

70. Shimizu T, Tolcher AW, Papadopoulos KP, Beeram M, Rasco DW, Smith LS, Gunn S, Smetzer L, Mays TA, Kaiser B, Wick MJ, Alvarez C, Cavazos A, Mangold GL and Patnaik A. The Clinical Effect of the Dual-Targeting Strategy Involving PI3K/AKT/mTOR and RAS/MEK/ ERK Pathways in Patients with Advanced Cancer. Clinical Cancer Research. 2012; 18:2316-2325.

71. Jain N, Curran E, Iyengar NM, Diaz-Flores E, Kunnavakkam R, Popplewell L, Kirschbaum MH, Karrison T, Erba HP, Green M, Poire X, Koval G, Shannon K, Reddy PL, Joseph L, Atallah EL, et al. Phase II Study of the Oral MEK Inhibitor Selumetinib in Advanced Acute Myelogenous Leukemia: A University of Chicago Phase II Consortium Trial. Clinical Cancer Research. 2014; 20:490498.

72. de Boer J, Williams A, Skavdis G, Harker N, Coles M, Tolaini M, Norton T, Williams K, Roderick K, Potocnik AJ and Kioussis D. Transgenic mice with hematopoietic and lymphoid specific expression of Cre. Eur J Immunol. 2003; 33:314-325. 
73. Hawley RG, Lieu FH, Fong AZ and Hawley TS. Versatile retroviral vectors for potential use in gene therapy. Gene Ther. 1994; 1:136-138.

74. Van Parijs L, Refaeli Y, Lord JD, Nelson BH, Abbas AK and Baltimore D. Uncoupling IL-2 signals that regulate $T$ cell proliferation, survival, and Fas-mediated activationinduced cell death. Immunity. 1999; 11:281-288.

75. Miller $\mathrm{AD}$ and Buttimore C. Redesign of retrovirus packaging cell lines to avoid recombination leading to helper virus production. Mol Cell Biol. 1986; 6:2895-2902.

76. Dow LE, Premsrirut PK, Zuber J, Fellmann C, McJunkin K, Miething C, Park Y, Dickins RA, Hannon GJ and Lowe SW. A pipeline for the generation of shRNA transgenic mice. Nat Protoc. 2012; 7:374-393.
77. Ran FA, Hsu PD, Wright J, Agarwala V, Scott DA and Zhang F. Genome engineering using the CRISPR-Cas9 system. Nat Protoc. 2013; 8:2281-2308.

78. McCurrach ME and Lowe SW. (2001). Chapter 9 Methods for studying pro- and antiapoptotic genes in nonimmortal cells. Methods in Cell Biology: Academic Press, pp. 197227. 